\title{
Living with Life-Threatening Illness
}

\author{
Teresa Foreman \\ Loyola University Chicago
}

Follow this and additional works at: https://ecommons.luc.edu/luc_theses

Part of the Psychology Commons

\section{Recommended Citation}

Foreman, Teresa, "Living with Life-Threatening Illness" (1977). Master's Theses. 2949.

https://ecommons.luc.edu/luc_theses/2949

This Thesis is brought to you for free and open access by the Theses and Dissertations at Loyola eCommons. It has been accepted for inclusion in Master's Theses by an authorized administrator of Loyola eCommons. For more information, please contact ecommons@luc.edu.

\section{(c) (i) $९$}

This work is licensed under a Creative Commons Attribution-Noncommercial-No Derivative Works 3.0 License.

Copyright (c) 1977 Teresa Foreman 
LIVING WITH LIFE-THREATENING ILLNESS

by

Teresa Foreman

A Thesis Submitted to the Faculty of the Graduate School of Loyola University of Chicago in Partial Fulfillment of the Requirements for the Degree of Master of Arts 


\section{ACKNOWLEDGEMENTS}

I would like to thank Dr. Pat Barger for providing guidance and encouragement throughout the preparation of this thesis. I am also indebted to $\mathrm{Dr}$. John Shack who provided inspiration at the beginning of the project and figured out a way to integrate the findings at the end. Special thanks to both of these busy people for being available for the last minute reading and revisions.

I am grateful to Dr. Janet Polivy for filling in on my committee and providing suggestions while Dr. Shack was in Rome. I am also grateful to Mary, Cheryl, and Dale for answering my many questions on procedures, and to all of the Guidance Center people who gave me support. Perhaps my largest debt of gratitude is to my subjects who gave me some of their limited time and taught me about their lives. 
VITA

Teresa Foreman is the daughter of Arthur Foreman Jr. and Marjorie (Greider) Foreman of David City, Nebraska. She was born August 19, 1950 in Hannibal, Missouri.

She attended the David City Public Schools for her elementary and high school education, graduating in 1968. At that time she was awarded recognition as a Merit Scholar and also granted a four-year Regents Scholarship to the University of Nebraska.

In June of 1968 she started classes at the University of Nebraska at Lincoln, and in December of 1971 she received the Bachelor of Arts degree with a major in psychology and minors in philosophy and math. She was elected to the Alpha Lambda Delta honorary in 1969, and to Phi Beta Kappa in 1971.

In September of 1972 she began graduate work in clinical psychology at Loyola University of Chicago. She began a traineeship at the Loyola University Guidance Center at that time, where she also did her clerkship, spending half time there for her first year, and three-quarters time her second year. September 1974 to September 1975 she did a full-time clinical internship at Michael Reese Hospital. June of 1976 she returned to the Loyala University Guidance Center and began a half-time administrative internship. 
Acknowledgements........................ il

vita..................................11i

List of Tables........................... v

Contents of Appendices...................... vi

Review of the Literature.................... 1

Personal Accounts................... 2

Fear of Death and Stages of Acceptance..... 3

Coping styles...................... 5

Hypotheses......................... 9

Method...............................11

Subjects..........................11

Materials........................11

Procedure.......................... 15

Results................................. 17

Individual Subject Data............... 24

Patterns Across Subjects.............. 52

Discussion.............................666

Limits of the Measures and Subject Sample...66

References.............................71

Appendix A...............................

Appendix B.............................

Appendix c.............................98

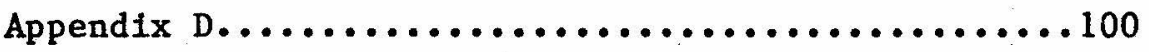

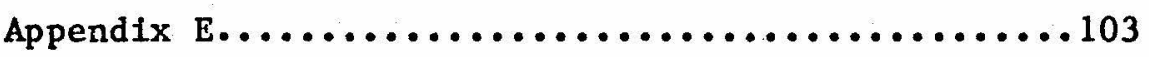




\section{LIST OF TABLES}

TABLE

Page

1. Subject Identification...................... 18

2. Ratio Scores on the Two Main P01 Scales:.......... 19 Time Incompetence/Competence and Outer/Inner Directedness

3. High and Low POI Subscale Scores for Each Subject... 20

4. Summary of Time Incompetent (Ti) Responses........ 21

5. Time Attitudes Responses of Subjects by Item....... 23 
CONTENTS OF APPENDICES

Page

Append1x A: Interview Format............... 73

Appendix B : Interview Write-Ups.............. 76

Appendix C: POI Standard Scores for Each Subject... 98

Appendix D: Time Attitudes Items with Positive... 100 and Negative Ratings and Significance

Levels of Items that Differentiated

Between Successful and Unsuccessful

Therapy Clients in Gendlin and Shlien

Study (Gendlin \& Shlien, 1961,

Table 2, p 70)

Appendix E: Time attitudes Items used In Results,. 103

Their Abbreviations, and Direction of

Scoring 
REVIEW OF THE LITERATURE

\begin{abstract}
"The thing to do when you're impatient," he proceded, "is to turn to your left and ask advice from your death. An immense amount of pettiness is dropped if your death makes a gesture to you, or if you catch a glimpse of it, or if you just have the feeling that your companion is there watching you." (Casteneda, 1972, p. 55)
\end{abstract}

Literature and philosophy are full of references to the value of getting acquainted with your death. The Ujpanishads suggest that it is the knowledge of death that helps man choose what is good over what is pleasant; Buddha similarly said that it was the knowledge of death that led man to overcome his craving for existence and started him on the path of enlightenment; the Bible says that it is this knowledge that causes us to "number our days so that we may get us a heart of wisdom" (Friedman, 1973, p. 150). A common idea is that the knowledge of one's death helps one live in the present. Krant (1974) suggested that all too many people wait too long to begin really living, but people who are made aware of their deaths find that there is no future to plan for, and so no longer have a need to try to become what one is not. Tillich (1959) similarly saw people as being "held by the past...or they escape towards the future, unable to rest in the present" (p. 37). He equated this inability to rest in the present with the inability to face the end of life. But once faced, Tillich believed that one experienced the eternal dimension of the present, and could rest there and enjoy it. 
Another aspect of facing death is facing the incomprehensible. Friedman (1973) said that the acceptance of death means the acceptance of a "dialogue with the Absurd, in which meaning is found in immediacy without any pretense at an overall, comprehensive meaning" (p. 160). Needleman (1973) continued this theme, suggesting that "there is something valuable about this ignorance" of just what death is, this recognition of lack of understanding and death and ourselves, the discovery that "our emotions surprise us" (p. 59). "Socrates," he noted, "was the wisest man in Athens, because he alone was aware of his ignorance" (p. 59), What Needleman suggested was that by being overwhelmed, by being forced to admit that one's categorles and maps cannot contain or explain all that one faces, one is led to a sense of wonder, to an openness to, or awareness of, something beyond oneself, to a transcending and freeing. Personal Accounts

A number of people including psychologists and psychiatrists have talked about their personal experiences with death in ways which seem to support some of the religious and philosophical propositions. Maslow reported that after surviving a massive heart attack his life was changed. "Everything gets doubly precious, gets piercingly important. I guess you could say that post-mortem life permits a kind of spontaneity that's greater than anything else could make possible" (cited in Sleeper, 1973, p. 133). Edward Albee, a playwright, said that "When I turned 36 or 37 I became avare that I, Edward Albee, was going to die.... I'm so much more 
aware of things azound me now. I find that I make love more of ten, and much better than before. I'm more aware of colors, of seasons, of textures" (clited in Sleeper, 1973, p. 135). Lauren Trombley (1972), a young psychiatrist dying of acute leukemia, reported his experiences while facing death, and he found himself doing some of the things he'd always wanted to do but had put off. He noted, "Sometimes it takes a crisis in an individual's life to get him to do the things that he could well have done all along to change his 1ife for the better" (p. 28). Also he reported:

I found I became increasingly aware of a new sensitivity that had gradually but progressively developed in my interpersonal relationships, both with patients and with all my acquaintances.... I was very much more tolerant of the vagaries and inconsistencies of other people's attitudes and behavior .... I found myself perceiving very quickly what lay beneath a particular person's atititude or affect.... I found that my own feelings were muct more accessible to my conscious recognition than they had been in the past. I also found that all of my senses seemed more acute.... The world seemed to offer more beauty.... There appeared to me to be a culmination of all the learning experiences that $I$ had in my professional career which in a compressed space of time, became the foundation for practically a new way of life... There was quite suddenly an integration of all values and understanding $I$ had of human experience 1nto some kind of cohesive whole.... (pp. 23-33).

Fear of Death and Stages of Acceptance.

So some people indicate that their lives are improved after catching a glimpse of their deaths. The trick may be that, as Don Juan suggests, one must turn to face one's death before one can benefit from its advice. There is ample evidence that people tend to use denial and other defenses to avoid looking at death. Wahl (1959) complains that the fear of death is not talked about in our society, and that even the psychiatric literature deals with death 
very little, and only as a permutation of castration anxiety.' And yet the fear of death is common from age three on. Feifel, Frei1.1ck, and Hermann (1973) studied the fear of death in 35 cancer patients, 33 heart patients, and 95 healthy individuals, at the conscious level by asking direct questions, at the fantasy level by asking subjects to visualize death, and at the unconscious level by using a word-association test and a color-word-interference test. They found that over $70 \%$ of each group denied any fear of death at al1. However, all groups visualized death ambivalently, and the two terminally ill groups showed significantly more fear at the unconsious level. Freud, in his "Thoughts for the Times on War and Death", which he wrote after his own diagnosis of cancer, noted that "to deal frankly with the psychology of death has the merit of taking more into account the true state of affairs and in making life more endurable for us" (cited in Wah1, 1959, p. 29).

Kubler-Ross (1969), as well as others, has complained of our society's encouragement to the individual to avoid facing death. Perhaps as a result, most people, once confronted with their deaths, must go through a series of painful steps in coming to accept it. These steps she listed as: (1) Denial and isolation, or "no, not me"; (2.) Anger, or "why me?"; (3) Bargaining, e.g., "I will be a better Christian if..."; (4) Depression, or "yes me"; and (5) Acceptance. People can become stymied at any one of the earlier stages and never reach the stage of peaceful acceptance. It was Kubler-Ross's intention to help people move through these 
stages as easily as possible. Nighswonger (1972) documented a nearly identical set of stages: (1) Shock--denial vs. panic; (2) Emotion---catharsis vs. depression; (3) Negotiation--bargaining vs. selling out; (4) Cognition--realistic hope vs. despair; (5) Committment--acceptance vs. resignation; and an additional stage, (6) Completion--fulfillment vs. forlorness. Inherent in his list are the pitfalls to be encountered at each stage. Miller (1975) found basically these same stages in the parents of children dying of leukemia, noting the stages of dental, anger, despair, and acceptance. He also found that most of the parents had to go through these stages after each remission the child had. The list of Chodoff, Freedman and Hamburg (1963) of stages parents go through, while somewhat different, contained the same basic elements; (1) Stun, a sense of unreality; (2) Split, intellectual acceptance with emotional non-acceptance; (3) More emotional vulnerability; (4) Anticipatory mourning; (5) Resentment and suspiciousness of doctors; and (6) Relief and calm (at child's death).

\section{Coping Styles}

It seems that most people, when faced with imminent death, do come to grips with it. To Hutschnecker (1959) it seemed "almost certain that deep within themselves, most patients know when they are going to die, and most of them are ready" (p. 238). But Hutschnecker also had "the tragic realization of how wany people enter their terminal disease with a sense of defeat, failure, and 
unfulfillment" (p. 237). It seems that there would be some advantage to getting ready for death before one's time was up. But can people do that? Maslow and Albee might be exceptional people in being able to take advantage of their early glimpses of death. There would likely be major individual differences in how people would handle foreknowledge of their deaths. Shneidman (1966) made the observation that dying styles are consistent with the individual's style of coping with living. Feifel (cited in Shneidman, 1956) noted that individual reactions to impending death vary with psychological maturity, basic coping strategies, religious orientation, age, socioeconomic status, severity of illness, and the attitudes of significant others. Davies, Quinlan, McKegney, and Kimbal (1973) in stuaying dying cancer patients found that of the patients they studied, those with mild intellectual impairment survived longer, slept and adapted to their illneses better, showed less dependency and less apathy, and were better liked by hospital staff. This might mean that many people are not abie to use clear intellectual knowledge of their impending deaths and do better if their thinking is not so clear. Janis (1971) in his study of surgery patients found.that his subjects tended to fall into three categories: Those with low anticipatory fear, those with moderate fear, and those with high fear. Each group reacted to the stress of surgery and recovery in a characteristic way: The first group became angry, anxious, and depressed; the second became model patients; and the third group became dependant and anxious. Each 
group also had a characteristic mode of seeking reassurance: The first group sought support for thej.z denial; the second group sought realistic information; and the third group were unable to accept reassurance of any kind. Chodoff et. al. (1963) noted different coping strategies in the parents they studied: isolation of affect in some, denial with optimism or denial with anger at doctors in others, and a lot of motor activity in the rest. Most sought some kind of meaning in their child's illness, but some sought it in the etiology of the disease, some in assigning blame, some in religion, and some in the possibility of the research value of their child's case. In the anticipatory grief stage, some showed somatic symptoms, some became detached and phlosophical, and in some parents their denial prohibited mourning. Kubler-Ross (1973) similarly mentions the few patients who stay in the denial stage, and the various ways other patients handle subsequent stages.

There are a number of studies which indicate that environmental factors have a major impact on the patient's adjustment. Glaser and Strauss (1966) described different environments in terms of different "awareness contexts", the contexts being defined by who knows and who admits they know that the patient is dying. They found quite different styles of adaption and maladaption depending on the awareness context. Sheehy (1973) looked at similar variables but primarily just between the patient and his spouse, instead of including the hospital staff. He concluded that the best adjust- 
ments were made by patienis whose spouses treated the situation according to a pretense, as if there were no fatal illness, and that actual acceptance of dying by the patient led to pretense behaviour. This may be in conflict with Kubler-Ross's, Glaser's and other's findings that open awareness and ability to talk frankly about the illness are most helpful. LeShan and LeShan (1973) did psychotherapy with dying cancer patients, and found that by indicating to the patient that he was valued, by spending the time with him to do therapy even though the patient would not have years to come in which to live a productive life, the patient was given a sense of self-worth and the value of the here-and-now, and accepted death more peacefully.

Individual differences in images of death have been looked at as well. Hutschnecker (1959) found that some patients viewed death from a dependent position, seeing it as a sort of return-to-thewomb; others saw it as something to be fought, and sought to "die with their boots on". Children's images have also been studied. Nagy (1959) interviewed 378 children and found that children under five usually thought of death as being like sleep and as being temporary. Children from five to nine generally personified death, and thought it would take you if you were bad. Children over nine frequently had learned the adult concept of death as the end of bodily life. Wahl (1959) saw children as viewing death as punishment, primarily for death wishes against their parents, and thought that children never viewed death as the result of chance or natural 
happenings, but always as having personal motives behind it. Vernon, Foley, Sipowicz, and Schulman (1965), in their review of studies of children's responses to hospitalization, found that children saw their illness and hospitalization as punishment for having been bad, and usually had their feelings of guilt alleviated by surgical procedures. Janis (1958) found similar reactions in some of his adult patients--a post-stress elation and respite from neutrotic symptoms apparently brought on by the sense of having paid the penalty and so being freed from guilt, for the moment at least. Abrams and Finesinger (1953) studied 60 cancer patients who foresaw no certain cures, and found that 56 of them expressed guilt as the predominating affect, even above anxiety. Hypotheses

Krant (1974) noted that "the majority of Americans today will die of chronic illness" (p. 33), and so they will have their approaching death pointed out to them before they must finish up their living. But will they find any advantage in this foreknowledge, or only disadvantage? The 1iterature suggests that people may make dramatic changes in their life styles and modes of experlencing when faced with a life-threatening 111ness. However, many people use denial and avoidance to deal with the knowledge of their deaths, and the literature suggests on the one hand that this prevents acceptance of death and is maladaptive, and on the otiar hand, that mental impairment or pretense behavior may be adaptive. This study was undertaken to investigate the question of whether 
people could make use of foreknowledge of daath to improve their living. The intention was to broadly explore with a few people how they adapted to this knowledge, and what changes they perceived in their lives since becoming ill. If subjects did report positive changes in their lives which were related to becoming $i 11$, then an additional purpose of this study was to sift out those aspects of their lives which seemed subject to this change, to identify variables for further study in a manner not so dependent on retrospective report. 
METHOD

\section{Subjects}

Subjects were peopie with known life-threatening ijlnesses of a chronic nature. They were located through available sources, through doctors and through friends. People of varying backgrounds were sought, but the most important criterion was that they were willing and able to talk about their experiences with their

\section{ilinesses.}

Nine people were interviewed. They ranged in age from 21 to 78, in education from a junior high dropout to $\mathrm{PhD}^{\prime} \mathrm{s}$, in occupation from unemployed working class to college professor and author. Five were women and four were men. One subject was black, the others white; one was from a Jewish background, three were from Protestant backgrounds, and five from Catholic ones. Illnesses included kidney failure, several types of cancer, and one case of lupus erythematosis-systemic. Life expectancies ranged from hope for recovery and a normal life-span to hopes for a few wore years; one subject died before all of the data was collected.

\section{Materials}

The basis for this study was an informal interview witn each subject. The cutline of questions covered is in Appendix A. Additionally, two self-report tests were used, the Personal Orientation Inventory (POI), a published test devaloped by E. L. Shostrom (available through Educational and Industrial Testiúg Service, San Diego, California 92107), and a time attitudes scale developed by 
Gendlin and Schlien (1961).

The POI is a self-report instrument designed to assess values, attitudes, and behavior relevant to Maslow's concept of the selfactualizing person. It consists of 150 two-choice items; each iten is scored twice, first for the two basic scales, inner directed support (127 items) and time competence (23 items), and second for ten subscales. Inner support (I) is defined as being "guided primarily by internalized principles and motivations, while other directed (0) persons are to a great extent influenced by their peer group or other external forces" (E. Shostrom, 1966, p. 4). Time competance $(\mathrm{Tc})$ is defined as living "primarily in the present with full awareness, contact, and full feeling reactivity, while the time incompetent (Ti) person lives primarily in the past, with guilts, regrets, and resentments, and/or in the future with idealized goals, plans, expectations, predictions and fears" (Shostrom, 1966, p. 4). The 10 subscales are grouped into five facets of the self-actualizing person. The first is interpersonal values, represented by the scale, Self-Actualizing Values (SAV), which measures how similar a person's values are to those held by a self-actualizing person, and by the scale, Existentiality (Ex), which measures one's flexibility and good judgement in applying values to one's life. The second facet is responsiveness to one's feelings, represented by the scale, Feeling Reactivity (Fr), a measure of sensitivity to one's own needs and feelings, and the scale, Spontaneity (S), measuring the ability to express 
-

feelings in spontaneous action. The third facet is atticudes towards self; represented by the scale Self-Regard $(\mathrm{Sr})$, measuring the ability to like one's self because of one's strengths, and the scale SeIfAcceptance ( $\mathrm{Sa}$ ), measuring acceptance of one's self in spite of weaknesses. The fourth facet is conceived of as general awareness, represented by Nature of $\underset{0}{ }$, Constructive (Nc), a measure of how much one sees man as essentially good, and by Synergy (Sy), a measure of . the ability to see opposites of life as meaningfully related. The last facet is interpersonal sensitivity, represented by Acceptance of Aggression (A), a measure of the ability to accept anger within one's self as natural, and by Capacity for Intimate Contact (C), a measure of the ablitty to develop meaningful, contactful relationships with others. The 10 gubscales have considerable overlap of Items; but the I and Tc scales are independent. Test-retest reliability coefficients for $T^{\circ}$ and $I$ are given as 0.71 and 0.77 respectively; for the 10 subscales reliabilities vary from 0.52 to 0:82: The test has good content validity. Results of a study . comparing a group of 29 people clinically judged as high in self-. actualization with a group of 34 judged $18 \mathrm{w}$ in self-actualization showed that 11 of the 12 scales discriminated significantly between the two groups. Five of six therapy studies slowed scores to rise significantly"after psychotherapy for patient groups, with control groups not changing over the same length of time.

Normative data is based on 2,607 entering college freshmen, but comparison profiles are provided for nonstudent groups as well. 
Raw scores are converted to standard scores, with a mean of 50 , and a standard deviation of 10 . Higher scores in general mean greater self-actualization, although when scores are consistently mell above 60 they are sometimes suspect, indicating the testee is describing himself unrealistically. The two basic scales I and Tc are often reported as ratios $0: I$ and $T i: T c$, partly to emphasize that the self-actualizing person is not always totally innerdirected or present-focused.

The items of the Tc scale can, for the most part, be divided into three groups: those items refering to how much a person Iives In the past, hampered by regrets and resentments (Past $\mathrm{Ti}$ ), those items measuring how much a person lives for the future, controlled by goals, expectations, and fears (Future Ti), and those items refering to how much a person experiences the past, present, and future as a meaningful continuum, instead of finding them unconnected, and therefore finding present experience and activities meaningless (Unconnected $\mathrm{Ti}$ ). The 23 items of the $\mathrm{Tc}$ scale are listed in Appendix B, with the group to which they are relevant indicated (Past, Future, or Unconnected).

The time attitudes scale developed by Gendlin and Shlien (1961) was designed to measure immediacy of experiencing before and after time-1imited psychotherapy. They developed the items by collecting a large number of personally expressive statements relevant to time attitudes, and from these, 37 itens were selected by being judged "meaningful" by a majority of 15 counselors. 
Twenty-four of the items were also judged as positively or negatively relevant to their theory of immediacy of experiencing. The scale was then given to 45 clinic clients as an unforced Q-sort. The positive and negative items were validated in that the 12 clients that had the highest overall scores placed each of the positive items higher than any of the negative items. Also, 16 items differentiated successful from unsuccessful clients $(p<.05)$ after therapy. One item differentiated these clients before therapy. All items are listed in Apendix D; those items with positive or differentiating qualities are noted.

In the Results section, only those items of the time-attitudes scale which could be related to the POI Tc scaie are summarized. This included three Past Ti items, four Future Ti items, and three Unconnected $T i$ items. In addition, two items which related to attachment and difficulty giving up attachments are presented. These 12 items, and the categories into which they fell are 1 isted In Appendix E.

\section{Procedure}

Subjects were contacted by phone and the nature of the study was explained. Interviews were arranged at the subject's home, place of business, or hospital, as was convenient. Most interviews were tape-recorded; subjects 1,4 , and 9 were not, due to malfunctioning of the interviewer's tape-recorder unit. Questions on the outline were introduced, and subjects were encouraged to talk about their history and experiences as they liked. The interviewer 
shared her experiences when asked to or when she deemed it helfful to the subject relating his or her experiences. At the end ot the Interview, subjects were asked to take the POI, with the instructions to take it in the usual manner, but for any items they thought they would have answered differently before becoming ill, they were to circle the number of those items. For Subject 8 the time attitudes scale was also give at this time. For the other subjects this scale was mailed to them, since it was added to the study after those interviews were done. Instructions for this scale were to rate the 37 items by putting the numbers of the items in boxes labled "Strongly Agree", "Agree", "Neutral", "Disagree" or "Strongly Disagree". In addition, subjects were to rate any 1tems a second time that they thought they would have answered differently before becoming 111 , by putting the numbers of those items in a second set of boxes labeled "Different Before". 
RESULTC

Subjects are identified by number, the numbers being assigned from " 1 " to "g" starting with the oldest subject. Table 1 lists the subjects alcng with their identifying characteristics.

Table 2 gives subjects ratio scores on the two main POI scales: Time Competence/Incompetence and Inner/Outer Directedness. Table 3 gives a partial picture of each subject's POI profile, by listing each subject's highest and lowest subscales.

Standard scores for all subscales are given in Appendix C. Table 4 summarizes subject's responses on the time competence items of the POI as well as on selected time attitude items, by 1 isting the number of $T i$ responses each subject gave in each category of items. As explained in the Methods section, time attitudes items were selected for the Past, Future and Unconnected categories on the basis of their similarity to the corresponding POI items. In addition, two items are listed that were related, in that subjects tended to agree with both or disagree with both, and the content was related to attachment and difficulty giving up attachments. Table 5 1ists the 12 time attitudes items used for Table 4 and indicates each subject's response on each. The primary purpose of the tables is to present this data so that it may be referred to easily. Comparisons across subjects may be misleading since many factors besices illness enter into the differences between subjects.

Interview data is summarized by demographic sketches of each subject including their experiences with their illnesses, and then 
Table 1

\section{Subject Identification}

\begin{tabular}{|c|c|c|c|c|c|c|}
\hline Subject & Age & $\underline{\text { Sex }}$ & IIIness & Occupation & Time Since $\mathrm{Dx}$ & Life Expectancy \\
\hline 1 & 78 & F & Leukemia & Retired Home-maker & $2-3$ Years & A few years \\
\hline 2 & 58 & F & Cancer & $\begin{array}{l}\text { Writer; Retired } \\
\text { Teacher }\end{array}$ & 10 Years & A few years \\
\hline 3 & 52 & M & Leukemia & $\begin{array}{l}\text { Writer; College } \\
\text { Teacher }\end{array}$ & 11 Years & Indefinite \\
\hline 4 & 36 & M & Kidney & $\begin{array}{l}\text { Part-time Boat } \\
\text { Business }\end{array}$ & $7-8$ Years & Indefinite \\
\hline 5 & 30 & $\mathbf{F}$ & Lupus & $\begin{array}{l}\text { Clinical Psych- } \\
\text { ologist }\end{array}$ & 8 Years & Indefinite \\
\hline 6 & 28 & $\mathbf{F}$ & Kidney & Secretary & 3 Years & Hoped Cure \\
\hline 7 & 26 & M & Kidney & Graduate Student & 7 Years & Indefinite \\
\hline 8. & 23 & M & Hodgkins & College Student & $11 / 2$ Years & Hoped Cure \\
\hline 9 & 21 & F & Leukemia & Home-maker & 4 Years & Indefinite \\
\hline
\end{tabular}


Table 2

Ratio Scores on the Two Main POI Scales: Time Incompetence/ Competence and Outer/Inner Directedness

Subjects

$\underline{T 1: T c}$

$\underline{0: I}$

\begin{tabular}{|c|c|c|c|c|c|}
\hline 1 & $1: 2.8$ & $(\text { Non-SA })^{a}$ & & $1: 1.2$ & (Non-SA) \\
\hline 2 & $1: 2.8$ & (Non-SA) & & $1: 4.3$ & (SA) \\
\hline 3. & $1: 3$ & (Normal) & $\cdot$ & $1: 2.9$ & (Norma1) \\
\hline 4 & $1: 3.6$ & (Norma1) & & $1: 3.9$ & $(\mathrm{SA})$ \\
\hline 5 & $1: 9.5$ & (SA) & & $1: 1.9$ & (Norma1) \\
\hline 6 & $1: 1.9$ & (Non-SA) & & $1: 2$ & (Normal) \\
\hline 7 & $1: 3$ & (Normal) & & $1: 3.8$ & (SA) \\
\hline 8 & $1: 10.5$ & $(\mathrm{SA})$ & & $1: 3.4$ & (SA) \\
\hline & $1: 1.1$ & (Non-SA) & & & (Non-SA) \\
\hline
\end{tabular}

a (Non-SA) means ratio is in the non-self-actualizing range. 
$\underline{\text { Tabje }} \underline{3}$

High and Low POI Subscale Scores for Each Subject

\begin{tabular}{|c|c|c|c|c|}
\hline Subjects & Highest & Also High & Lowest & Also Low \\
\hline 1 & $S x^{a}$ & - & s & C \\
\hline 2 & $\mathrm{Sa}$ & S, Sy, A & $\mathrm{Nc}$ & -- \\
\hline 3 & SAV & $\mathrm{Sr}, \mathrm{Sa}, \mathrm{Sy}$ & C & Fr \\
\hline 4 & SAV & $\mathrm{A}, \mathrm{Sr}, \mathrm{S}, \mathrm{Sa}$ & $\mathrm{Ex}$ & Fr \\
\hline 5 & Ex & $\mathrm{Fr}, \mathrm{SAV}$ & $\mathrm{Sr}$ & - \\
\hline 6 & $\mathrm{NC}$ & - & Ex & Sy \\
\hline 7 & SAV & $\mathrm{s}, \mathrm{C}$ & $\mathrm{Sa}$ & $\mathrm{Nc}$ \\
\hline 8 & C & $\mathrm{Sr}, \mathrm{SAV}$ & Sy & $\mathrm{Sa}$ \\
\hline 9 & Sy & $\mathrm{Nc}, \mathrm{Sa}$ & Fr & $A, C$ \\
\hline
\end{tabular}

a Abbreviations are explained in Methods Section. 
$\underline{\text { Table }} \underline{4}$

Summary of Time Incompetent (Ti) Responses

POI Ti Responses

\section{Past}

Future

Unconnected

Qther

Time Attitudes $\mathrm{TI}$

Responses

Past

Future

Unconnected

1

$\underline{2} \quad \underline{3} \quad \underline{4}$

$6(+4)^{a} 6(+3)$

2

3

$2(+2)$

$2(+3)$

$0(+2) \quad 0$

2

1

2

$\underline{5}$

$6 \quad \underline{7}$

ㅇ. $\quad \underline{9}$

6

12

$2(+9)$

$85(+1)$

$2(-2) \quad 9$

$1(+5)$

$2-1$

02

3

3

$1(+3)$

$2(+1)$

$1(-1) \quad 4$

00

(20)

0

1

$1(-1) \quad 2$

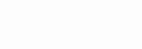

$+2$

1

3

0

$6(-2)$

5

4

$1(+2)$

1

0

1

1

$0(+1) \quad-$

1

1

0 - $2(+1)$

$22(+1)$

$0(+1) \quad-\cdots$

2

1

$0 \quad-3(-3)$

$21(+1)$

Time Attitudes Attachment Responses

2

$1 \quad-\quad 0(+1)$

1

0

$0(+1) \quad--$

a Numbers in parentheses are "Different Before" response, e.g., (+4) means subject indicatec she would have answered four more items in the Ti direction before she was 111. 
Time Att1tudes Responses of Subjects by Item

Past Items: Tc Direction

\section{Strong1y Agree (Strongly Disagree) (Disagree)}

9. Fresh 0pportunity ${ }^{\mathrm{a}}$ (Agree) $^{\mathrm{b}} 6,6$

(8), (5)

23. Nothing to show (Disagree)

5

26. Work, then forget (Agree)

Future Items:

16. Too Worried (Disagree)

$8,(3)$

3,8

24. Do to look back (Disagree) $2,6,7,(5)$

28. Need deadline (Disagree)

17. Do nothing (Disagree)

2,3

1

1,5

1,6

$$
1,2,3,7,(5)
$$

$$
1,3,5
$$$$
2,3,6,8,(7)
$$

8

7,5

$2,6,7$

$1,(8)$

\section{T1 Direction}

$\frac{\text { Disagree }}{\text { (Agree) }} \quad \frac{\text { Strongly Disagree }}{\text { (Strongly } 1 \text { Agree) }}$

5

7

$1,5,6$

$2,5,6$

$7,(5)$

3,8

(7)

3,8

$2,5,7$

$(8),(5)$ 
Table 5 (continued)

Unconnected Items:

\section{Tine fleeting (Disagree)}

2. Pace too fast (Disagree)

22. Minute too small (Disagree)
$3,(7)$

$1,2,3$

Unattached Direction

\section{Strongly Disagree}

\section{At tachment Items:}

32. Like owning (Disagree)

7

36. Hard goodbyes (Disagree)

$$
1,5,8
$$

5,7
3

$2,6,7$

7,5

5,6

$1,2,6,(7)$ 5,7 8

a Complete items are 1isted in Appendix E.

"(Agree)" means that to agree to the item is to answer in the time competent direction. For both Attachwent Items, to disagree is to answer in the unattached direction.

b Subjects are identified by number. Numbers in parentheses mean that subject indicated he or she would have answered that way before he or she was 111 . 
a taliy of how tiney responaed to these items: (1) life expectancy;

(2) experience with the medical profession; (3) other relationships;

(4) self-image; (5) religiousity and meaning in 1ife; (6) image of death and fear of death; (7) worries, and ways of avoiding worrying; (8) Iife satisfaction; and (9) perceived changes in values, attitudes, and experiencing stemming from illness. (More complete write-ups of the interviews are in Appendix B.) POI data and tine attitudes data are also summarized for each subject.

The last section of the Results is a synthesis of subjects responses, a description of patterns that occurred across subjects on some items.

Individual Subject Data

Subject 1 was a 78 year-old Jewish woman living by herself in a small apartment on the Near North Side. A widow of 14 years, she had one son living in California and one daughter in the suburbs, as we11 as six grandchildren that she visited occassionally. Subject 1 had chronic myelogenous leukemia which she had found out about two years ago when her old doctor died and she had to go to a new one. She had suspected something was wrong with her for some time, but thought her old doctor hadn't the heart to tell her. She thought her real physical problems were more directly related to old age, however. She had a chronic bladder infection, little energy and didn't sleep we11. She didn't entertain anywore because it was too taxing, but she went out to visit friends and fanily, and she went to concerts. When asked about changes she had exper- 
lenced since becoming 111, she said it really hadn't made much difference to her at 76, and so she answered those questions on the basis of change since becoming old and widowed.

1. Subject 1 didn't know much about her illness, but said, "I know it is chronic, and so I suspect it will outlive ne--I'm 78."

2. She said her old doctor had been wonderful. Her new internist was okay, but she liked her hematologist very well and was satisfied with her treatment.

3. She said she didn't tell people about her 1llness, but she thought her friends knew she had it. Growing old had meant the death of her husband and then of her sister, whom she had cared for through a long illness. Aging also had meant that many of her friends had died or were incapacitated. Now, she said, she just tried to be a good companion to friends, and she didn't much bother with people she didn't like. She tried to maintain her independence, but she was not as strong a before; that day she had had to have her son-in-law come over to fold up her hew hide-away bed which was stuck.

4. She said she used to be strong for others, her husband and children, and later, her sister. Now, she said, she had become "just like other widows--they get mean. You have to take care of yourself."

5. She said she was not religious, although she wished she were. It was friends and family that made life worthwhile, she thought. 
6. She had no religious belief in a supernatural being or an afterlife, but she said death was not frightening to her. However, being sick and unable to take care of herself or remember things, as many of her friends had become, was frightening.

7. Subject 1 said she didn't worry much about her illness or being sick, but that she did worry a lot about "crazy little things", like the bed.

8. She saw her past as good. Some of it had been hard, like during the Depression, but raising a family had been very satisfying. Now, she said, she just tried to take things as they came and not make a fuss of anything.

9. In her past Subject 1 had lived primarily for others who had needed her. Now, she said, "I just try to be a good companion to friends and amuse myself a little." She saw herself as having become more tolerant of others when their behavior did not meet up to her values, such as with her grandchildren. Also, she thought she used to not procrastinate, but now she had so much time on her hands it didn't matter. '

POI data. Subject $1^{\prime}$ 's Ti:Tc ratio was in the non-selfactualizing range; her $0: I$ ratio was in the normal range. Her highest subscale score was in Self-Regard; her two lowest scores were on Spontaneity and Capacity for Intimate Contact. Of the six Time Incompetent (Ti) items she subscribed to, two were Past items, and two were Future items. However, of the items she thought she would have answered differently before, four would have been $\mathrm{Ti}$ 
answers, two being Future and two Unconnected items.

Time attitudes data. On the ten time attitudes items Subject 1 gave $\mathrm{TI}$ responses to four items: one Past, one Future, and two Unconnected. On Past 1tems she indlcated that she experienced each day as a fresh opportunity, and that she was not disturbed by having nothing to show for her time, but that she was not able to work hard on a task and then relax and forget it. On Future items she indicated that she was not distracted by having too much to do, that she did not need deadiines to get her started, and that she didn't do things she didn't enjoy just to look back on them later, but that she did often find herself too worried about what might happen in the future and to be really absorbed in present activity. On Unconnected Items she indicated she did not experience time as fleeting or in short supply; neither did she find the pace of life too fast, but that she did find a minute to be too short to be useful. Subject 1 described herself as basically unattached on the Attachment items, indicating she had no desire to own things she couldn't use and that saying goodbye was not particularly hard for her.

Subject 2 was a 58-year-o1d white married woman with a doctorate in psychology. She had taught college for 20 years, published two books, and raised three children. She could no longer teach, but kept busy writing, doing handiwork, volunteering for the American Cancer Society, and taking trips with her husband. She had had a masectomy 10 years earlier; two years ago part of her jaw 
had been removed, leaving her with some difficulty talking and eating. Now she had cancer in her bones and lung, but had been feeling pretty good for a couple of months since starting a new medicine.

1. Subject 2 said she hoped to live to go to her college reunion three years hence.

2. She liked her doctors as individuals, and she said they treated her as someone special. She also respected some of their skills, like her jaw-surgeon's cleverness in designing her a jowl to hide the scar and that now nearly matched the jowl forming on . the other side of her face. However, she had major misgivings about the standard medical treatments she had been subjected to. She saw some of the procedures used in Europe, as well as more recently developed American procedures, as less devastating. For instance, her ovaries had been removed soon after her masectomy, an operation she understood was judged to be of little value and discontinued less than a year later, but physically it had been a more tramatic operation than the masectomy. Also, she said she had complained of head pains for a full year before they investigated and found cancer in her jaw. She thought the operation would not have been so severe if done earlier. But she felt she had the right to not suffer, to not feel pain, and was confident that her doctors could help her with that.

3. Subject 2 thought people paid more attention to her now that they didn't know how long she would be around. Also, she got 
closer to people now, since she had more time free now, and since she realized how important relationships were. She avoided telling new acquaintances about her illness, though, because many didn't handle the news well.

4. She saw herself as being more dependent on her husband, but also stronger in being more courageous and more self-directed. 5. Subject 2 had a strong faith of a Unitarian nature, and she thought life was made worthwhile through "interacting with people in a supportive way, in doing worthwhile things, and in giving back to the world that has helped to make you."

6. She saw death as peaceful, and said it didn't bother her that she wouldn't live to be 80 or 90 . She talked of death as a rebirth, like the transformation of the fetus into the infant, and she did not fear it.

7. She said she had not considered herself to have cancer until recently, when an X-ray had shown cancer all over. After her breast and jaw operations she had figured each time that when the tumor was removed and she was recovered from the operation, then it was all over. Now, she said, she was resigned to dying from the cancer. But she worried most about her jaw, that the numbness would take over her whole mouth and she wouldn't be able to talk. Subject 2 emphasized that having goals and keeping busy were very important to her in making the rest of her life worthwhile.

8. She thought her life had always been good, but that it had been enriched in recent years because of her cancer: She had done 
things, such as writing and traveling and developing relationships, that she had been putting off before. She looked forward to doing more of these things she enjoyed, in the future.

9. Her plans had changed after she became 111: She could no longer teach, or plan to go into the Peace Corps after she retired. Also, she and her husband no longer put off trips or other planned activities for "when the children are grown", or "when we retire", but instead worked on doing those things now. She said she was much more aware of how long tasks were going to take now, and did not begin tasks she could not finish unless she could arrange with a friend to finish it if she could not, as she had done when she started another book. She noted that "actually arriving at one's goals becomes a way of 1ife". She also said she had cut out "unnecessary trivia" like some kinds of housework that she would have thought important before, and she bought lettuce if she wanted It without worrying about the price. For herself, she said she had dared "to defy the kinds of patterns that have become customary and do things a 1ittle differently."

POI data. Subject $2^{\prime}$ s Ti:Tc ratio was in the non-selfactualizing range; her $0: I$ ratio was in the self-actualizing range. Her subscale scores were fairly evenly high, with Self-Actualizing Value, Spontaneity, Synergy, and Acceptance of Aggression being highest. Nature of Man, Constructive was her lowest. of her six Ti answers, three were on Past items, and two were of Future items. She also had three Tc answers she thought she would have answered 
differently (i.e. Ti) before, and all were Future items.

Time attitudes data. Subject. 2 gave three Ti answers on these 1tems: one Past, one Future, and one Unconnected item. Subject 2 found each day a fresh opportunity, and she could relax and forget work after it was over, but she was sometimes disturbed if she had nothing to show for a period of time. She did not find herself too worried to be absorbed in present activity, and she did not do things she didn't enjoy just to be able to look back on them, but she did need a deadline to get herself started sometimes. Subject 2 found time to be fleeting and in short supply, but she also found a minute to be long enough to be useful. of all the subjects, Subject 2 indicated the strongest feelings of attachment by very much agreeing that she liked owning things even when she could not use them, and that saying goodbye was hard for her.

Subject 3 was a 52 year-old white psychology professor and writer of children's books, living with his wife and the younger of his two daughters. He had been diagnosed with chronic lymphocytic leukemia 11 years before, at which time he had been very sick, with severe headaches and considerable loss of sight. Since his eyes had cleared up, he had had no major physical crises, but just a gradual loss of strength, in part caused by the collapse of one lung due to the accumulation of lymphocytes in the lung cavity. A once athletic man, he now was unable to run five steps to catch a train, he said. But he was still a full-time professor, and continued publishing books. 
1. Subject 3 said they had given him 5 to 20 years to live at the time of his diagnosis and thought five was more likely. He figured one day he would catch a cold, it would turn into pneumonia, and that would be his end.

2. He was very pleased with his medical care. He trusted his doctor completely, he said, and would stand on his head if the man told him to. The hospital he had stayed at he described as "marvelous", and even the food was good.

3. Subject $3^{\prime}$ s first wife had left him when he became 111; she was a Christian Scientist and thought the 11lness was an indication of sin. However, he had remarried, and had regained custody of his children, as well as retaining a close relationship with his former mother-in-law. He noted that people had been quite sincerely concerned about him when he was first 111 , checking up on him frequently. When he failed to die at the appointed time, they had looked at him strangely, as if to say, "Here we put a.1 of this worry into you and you're still here!", and then relationships had reverted to normal. Subject 3 said that he did not talk to people about his illness; "People don't know what to do, and they"re embarrassed."

4. Subject-3 saw little change in his self-image. He knew he was physically not as strong as before, but as a writer and teacher he saw himself as becoming ever more effective.

5. He saw religion as primarily a social phenomenon; he had done his doctoral dissertation on 1t. But he believed that there 
was a god, and his orientation towards life was that "You do those things that make you happy, and make others happler--There is little enough you can do for others...."

6. He claimed no fear of death, nor any belief in an afterlife, but he figured people weren't bright enough to be able to know if there was one or not. If there was, he figured he would just adjust to that when the time came.

7. Subject 3 said he did not worry about his illness, but was more inclined to be irritated by it. He explained that since there was nothing he or his doctors could do about it, there was no point in worrying.

8. He said he was one of those lucky people for whom things always got better, and he was operating under the "perhaps naive" assumption that this would continue. He noted that his writing skills continued to Improve each year, and writing was highly satisfying to him.

9. He claimed no changes in values, attitudes, or experiencing because of his illness, except that perhaps it had contributed to his learning efficiency: "I've become much more effective in the things I do. Probably this comes from just getting older and more experienced, but also the urgency of time made me better faster...." Also now he chose more carefully among alternative activities, to spend his limited time and energy most valuably. Subject 3 noted that he had dealt with the issues of death and suffering while in the war, which had been at a time when his values and attitudes 
were still forming.

POI data. Subject $3^{\circ} \mathrm{s} T i: \mathrm{TC}$ ratio was in the normal range as was his $0: I$ ratio. HIs highest subscale was Self-Actualizing Value, with Self-Regard, Self-Acceptance, and Synergy also relatively high. HIs two lowest scores were in Capacity for Intimate Contact and Feeling Reactivity. Subject 3 omitted 14 items, however, which may have altered the pattern as well as the helght of subscales. Of his six $\mathrm{TI}$ answers, three were Future items, and one a Past item.

TIme attitudes data. Subject 3 gave no $T 1$ responses on these items, although he was neutral on two Future and one Unconnected item. He also gave no responses in the attachnent direction, although he was neutral on "Hard goodbyes".

He Indicated that he experienced each day as a fresh opportun1ty, that he could work hard and then relax and forget about the work, and that he was not disturbed by having nothing to show for a period of time. He did not find himself too worried to be absorbed in the present and he strongly disagreed that he might of ten do nothing because of having too much to do. He did not find the pace of life too fast, and he was able to find even a minute long enough to be usefui. Subject 3 took a basically unattached position on the Attachment items, disagreeing that he might like owning something he couldn't make use of, and being neutral on goodbyes being hard.

Subject 4 was a 36 year-old white Catholic man, married just 
seven months, unemployed, but with a college degree and several years of graduate school. The interview took place in his small apartment with his wife present. He had been diagnosed with chronic renal failure about the time he entered graduate school, and had been on dialysis for six years. He had survived three transplants and three rejections of kidneys; his own kidneys had been removed, and for some time he had been severely restricted in his activity by a very low hematocrit level which left him with little energy.

1. Subject 4 said he didn't expect to live as long as most people, and he only made plans for the near future. On the other hand, he said he was in as good shape now as he had been six years ago, and so the doctors didn't know how long he would survive.

2. He did not trust the medical profession. He reported receiving substandard medical treatment which had nearly cost him his life on more than one occassion, and said he would not accept another transplant unless he could-choose his surgical team.

3. He did not hold great faith in people in general, saying, "People are essentlally good, but can't be trusted" in response to a POI 1tem. He felt he had been unfairly treated at a number of points in his career, and he still felt some anger about it. On the other hand, he had recently and impulsively taken a wife, and he seemed to derive a good deal of satisfaction from this relationship in which he took a rather parental, care-takirig role. 
4. Subject 4 said he saw himself as stronger and more independent than he had been before his illness, which was also when he was younger. He noted his achievements, such as his work for the Kidney Foundation, and he talked of his potential achievements if only he had more energy.

5. He said he was a regular church attender and had a strong Catholic faith.

6. He understood death in a traditional Catholic way, but also he had had two near-death experiences which he described as very comfortable and peaceful, and so he had no fear of death.

7. Subject 4 said he worried more about his wife's health and how she would take care of herself if he died than he worried about his own health. A business venture that he hoped would support her was the focus of much of his concern.

8. In response to the question of life-satisfaction, he said that things had always continued to get better. When he was first out of college he had had an $\$ 18,000$ job and got to travel all over the United States, but 11fe was better now because he had his wife.

9. He was very aware of his physical limitations now, and the likeliness of being limited in time, and so he only planned for the near future now, and was also trying to teach his wife to take things easy and not worry, that most things, such as disposing of pop bottles, could wait.

POI data. Subject $4^{\circ} \mathrm{s}$ Ti:Tc ratio was in the normal range; his 0:I ratio was in the self-actuarlizing range. His highest 
subscale scores were in Self-Actualizing Value, and Acceptance of Aggression, with Self-Regard, Spontaneity, and Self-Acceptance also high. His lowest scores were Existentiality and Feeling Reactivity. of his five $\mathrm{Ti}$ answers, three were Future items, and two were Past 1tems.

Time attitude data was not obtained from this subject since he died before doing that questionaire.

Subject 5 was a 30 year-old white married woman with a doctorate in psychology. She was interviewed in her home with her husband participating. Eight years earlier she had had her first attack of lupus erythematosis-systemic, a disease in which the auto-immune system attacked various parts of the body; in her case it was her joints and blood. She had had two attacks in all and both times the drugs had caused considerable weight gain, hair loss, and toxic psychosis. At the time of the interview it had been about two years since her last attack.

1. Subject 5 understood that theoretically she could survive any number of attacks just as she had the first two, if the disease did not attack her kidneys, but she said she expected to die of the 111ness.

2. She followed her doctor's instructions, for instance, he had told her not to read up on her illness and so she had not. Also, she said she had enjoyed the regression one is allowed while hospitalized, but she had been misdiagnosed and mis-treated enough times that she didn't really trust the medical profession. 
3. She thought she had become closer to and more dependent on a few people, one being her husband, but with other people she felt more separate than before. She didn't talk to people much about her illness; she thought they couldn't really understand or help her with it.

4. Subject 5 said she didn't expect as much of herself as she did before she was sick, and she was more protective of herself, trying to avert another attack.

5. She said she had no religious beliefs and no belief in an afterlife. She found happiness in little things like an evening at home with her husband and popcorn and a good movie on TV.

6. Death she saw as the end of experience, like falling asleep, and she said it did not frighten her now. As a child, she had been very much afraid of death, but she had worked out those fears as an adolescent after her father died.

7. She said that after recovering from the first attack, she convinced herself that it wouldn't happen again, but after the second attack she worried about having another one. "I worry a lot," she said, "to the point of obsession."

8. She said her past had been hard, her present was hard, and she expected her future to be the same, but that there was some relief for her in the acceptance of that.

9. Subject 5 did not think her goals and values had changed since she had become ill, except that she didn't push herself as hard now and was more resigned to life as it was. 
POI data. Subject $5^{\prime}$ s Ti:Tc ratio was high in the selfactualizing range; her 0:I ratio was on the border between the normal and non-self-actualizing range. of her subscale scores, Existentiality, Feeling Reactivity, and Self-Actualizing Value were highest; Self-Regard was markedly lower than the others. of her two Ti answers, one was a Past item, and one a Future 1tem. She indicated nine other Tc items she would have answered differently, 1.e., Ti, before, and of these, five were Past items and three Future items.

Time attitudes data. Subject 5 gave $\mathrm{T} i$ responses to six items: one Past, two Future, and all three Unconnected. She was the only subject who denied experiencing every day as a fresh opportunity, but she indicated that it was different before she was 111, when she thought she would have agreed with the statement. She indicated that now she was effective at relaxing and forgetting work after it was finished (Different Before: neutral) and that having nothing to show for a period of time did not disturb her. She thought she did often feel too worried to be absorbed in present activity, and she did need a deadline to get started, but she didn't feel as strongly about either item now as she thought she would have before. She indicated she didn't do things she didn't enjoy just to be able to look back on them, although again she didn't feel as strongly about the item as she would have before she was ill.

Subject 5 felt more strongly than any other subject that the 
pace of life was too fast, although again she would have disagreed before, and she felt strongly that time was fleeting and in short supply, but indicated she would have strongly disagreed before. She agreed that a minute was too small to be of any use (Different Before: neutral). Subject 5 took an unattached position on both attachment items, denying that she liked owning useless things (Different Before: neutral) and that saying goodbye was hard for her, but she thought that saying goodbye used to be definitely hard for her.

Subject 6 was a 28 year-old white single woman, working as a secretary in a law firm and living in a two-bedroom apartment above her parents. She was interviewed at her office after work one evening. Born in Hungary, her family had moved to chicago when she was nine. The oldest of three children of working class parents, she had a high school education, supplemented by evening art classes. She had been diagnosed with high blood pressure and kidney damage in October of 73. - She was put on a low protein diet and medication to reduce her blood pressure which made her feel sluggish. By March of '75 she had to go on dialysis. In June she received a transplant from her mother which involved a four-week hospitalization and a lot of pain and anxiety, since the new kidney failed to function for three weeks. Since that time, she had been on much lower doses of blood pressure medicine, as well as being on Immuno-suppressants, but her energy was back, she was active and felt fine. 
1. Subject 6 said she expected to keep her kidney forever. She understood her original kidney damage to have been caused by some kidney infection or other damage, which then raised her blood pressure, causing more damage. But she saw that as a random, unlucky accident and saw no reason for it to reoccur. She also understood that kidney patients seldom had rejection crises after the first year or two, so she expected the best.

2. Subject 6 was quite happy with the medical people she had been involved with. Even the dialysis technicians, she said, had joked with her and cheered her up such that she actually had looked forward to going to dialysis.

3. She sald people had been very supportive to her when she was sick. Especially her mother had made her the center of attention. She felt closer to her mother now than before her illness and thought they had developed more of a friendship as well as mother-daughter relationship. Subject 6 tried to be more tolerant of other people's failings now, and not so short with them or belitt1ing.

4. She saw herself as more able to tolerate pain and more courageous in taking risks, although some of this change she related back to a car-train accident she had been in several years earlier in which she had broken an arm, but thought she could have lost her life.

5. She had been raised Catholic, but considered herself now agnostic, although she had prayed in the hospital when people were 
praying for her. Happiness she found in things like camping and traveling.

6. She saw death as leading to reincarnation, and she was not afraid of it.

7. Subject 6 said that after the transplant, she had at first worried about it rejecting with every cramp she had. But when nothing happened, she gradually quit worrying. Also, she would not let herself get down or worry now, since she figured she had cheated her fate twice and was living on borrowed time.

8. She said her past had been good, but she had been unsure of herself and felt inferior. She said her present life was good, but she always wanted more, as in wanting marriage, but she expected things to continue getting better in the future.

9. About her new kidney she sald, "Who knows how long I'11 have it, so why worry on borrowed time?" She said she didn't do things that much differently, but that her frame of mind was better--she didn't let herself get depressed. Also, when she was in the hospital, she had prayed, promising to be nicer to people and not scoff or belittle them if she survived, and now she was working on living up to that.

POI data. Subject $6^{\circ} \mathrm{s} \mathrm{TI}: \mathrm{Tc}$ ratio was in the non-selfactualizing range; her $0: I$ ratio was in the normal range. of her subscale scores, Nature of Man, Constructive was markedly higher than the others; Existentiality and Synergy were her low scores. of her eight $\mathrm{Ti}$ answers, four were Future items, and two Past 
items.

Time attitudes data. Subject 6 gave five $T i$ responses to time attitudes items: one to a Past item and two each to Future items and Unconnected items. She strongly agreed that every day was a fresh opportunity for her, and she agreed that she could work hard and then relax and forget work, but she was sometimes disturbed by having nothing to show for a period of time. Subject 6 denied needing a deadline and strongly disagreed that she did things she didn't enjoy just to look back on them, but she agreed that she was of ten too worried about what might happen to be fully absorbed in the present. She found time to be fleeting and a minute to be too short to be useful. She found saying goodbye hard for her, but was neutral on liking to own things even if she couldn't use them. She agreed with one Attachment item and was neutral on the other.

Subject 7 was a 26 year-o1d white divorced graduate student in psychology living alone. He had grown up the youngest of three children in an Irish-Catholic family. He had been diagnosed with chronic renal fallure when he was 19 , and had gone on dialysis when he was 24. He had gotten a transplant six months later which was so far successful, but he still considered himself life-threatened, talking about the medicines he took to keep his blood pressure down and to prevent rejection of the kidney, and how they might interfere with his fighting off infection, such that he might have to go off the medicine, risking another rejection crisis. Also, the cause of the demise of his original kidneys was unknown, and the new one 
might go the way of the old.

1. Subject 7 hoped for 10 to 15 years of reasonable health with the new kidney, since the longest he knew of anyone keeping a transplanted kidney was 15 years. He figured he could go back on dialysis after that, but recognized the high mortality rate of dialysees, as well as the severe restrictions of that lifestyle.

2. He made no complaints about his own medical treatment, but thought that he had been lucky in getting a good surgeon; he talked of other doctors who lost a lot of transplant patients through shoddy work.

3. Subject 7 said that after his hospitalization and surgery, with the resultant loss of social role, the pain and anxiety, when he returned to the outside world, he found himself more tolerant in relationships, and this was a change he was trying to mainta1n.

4. He saw himself as more tolerant of other people, but also he had become more accepting of himself (POI and Time attitudes data), accepting his needs and limitations more.

5. He said he had called himself an atheist for some time, but now he found himself to be more an agnostic. He ascribed no meaning or purpose to life, but this was a conflict for him.

6. He said he believed that death was a non-experience, like before birth. But also he admitted to being terrified of death. He couldn't imagine going through Kubler-Ross's five stages, reaching the stage of acceptance of death, but thought instead that he would go out "kicking and spitting to the end." 
7. Subject 7 described himself as compulsively vigilant, explaining his "airplane fantasy": Whenever he was in an airplane, he never slept but kept alert and watched out the windows such that If he saw any danger he could run up and warn the pilot and thus avert disaster. He said he operated in a similar manner in regards to his kidney, protecting it as by not participating in rough sports, and staying alert to any signs of rejection.

8. He said that his childhood had been his best time--he had been quite close to his mother, and had enjoyed elementary and high school. In college he had gotten caught up in work and forgotten to take time to enjoy himself, and being sick and on dialysis had not been pleasant. Now he saw things as getting better again, but still not so good as childhood.

9. His experience after his hospitalization was that, as well as feeling more tolerant with people, he really appreciated the fresh afr and sunshine; he was trying to maintain both of these changes. He also was working at achteving a balance now, between working hard and helping others, and enjoying himself and "watching the river flow".

POI data. Subject $7^{\circ} \mathrm{s}$ Ti:Tc ratio was on the border between the normal and non-self-actualizing ranges; his $0: I$ ratio was in the self-actualizing range. His highest subscale scores were in Self-Actualizing Value, Spontaneity, and Capacity for Intimate Contact; his lowest scores were Self-Acceptance and Nature of Man, Constructive. Subject 7 omitted 16 items, which may have altered 
the relative height of his subscales as well as their absolute height. Of his five Ti answers, two were Future items, one a Past Item, and one Unconnected. Of his Tc answers, one of them, a Future item, he indicated he would have answered differently, i.e. Ti, before.

Time attitudes data. Subject 7 gave one Past, two Future, and one Unconnected Ti responses. He found each day a fresh opportunity, but he was disturbed by nothing to show for a period of time. He did not do things he didn't enjoy just to look back on them, although he thought he would have before he was ill. He agreed that he often did nothing because there were so many things he needed to do, and that he needed a deadline to get started. He found time to be fleeting and in short supply; he was neutral on the pace of life being too fast but thought he would have agreed with that before.

Subject 7 disagreed with both attachment items, strongly denying that he liked owning useless things, and disagreeing that saying goodbye was hard for him. He indicated that before he also would have agreed with "Do too look back" and "Pace too fast", one a Future and one a Unconnected $\mathrm{Ti}$ response. He subscribed to neither attachment item.

Subject 8 was a 23 year-old white Catholic man, a college student studying business. The youngest of six children, two of his sisters were now nuns, and one a teacher; his older brother was in real estate and the other still a student. Subject 8 lived with 
his retired father and his mother in rural Indiana. His mother had come with him to the hospital where he had come for tests that day and was with him during the interview. Subject 8 had been diagnosed with fourth stage Hodgkin's Disease (most advanced stage) a year and a half before. He had gone through an initial stage of paralysis from waist down, caused by a spinal tumor on which he had surgery and radiation treatment which had almost completely restored his functioning. Then he had had once or twice a week radiation and chemotherapy for the Hodgkins for about a year, which he admitted made him feel "downright lousy" each time. But now, he said, the tests showed consistant improvement. He was in partial remission and back taking classes full time.

1. Subject 8 hoped to recover and live a normal life-span. 2. He had found medical people quite helpful, although he now understood some of their limitations, such as X-rays do not always pick up things like spinal tunors.

3. He avolded talking to people outside of his family about his illness; with some of his best friends the topic had never come up. But from his family he felt that he had gotten a lot of support and encouragement, even though "at first it was awkward for them", unt1l they saw that he wasn't "going to pieces".

4. "You have to have a high opinion of yourself after something like that," he said, in regards to self image. He saw himself as stronger in being able to handle mental strain as well as physical pain. 
5. Subject 8 described himself as a strong Catholic. Meaning In life he thought came from "doing the best you can in your vocation or area of interest", and he got the most enjoyment from fulfilling commitments and doing things that helped other people.

6. He held a Catholic view of death and figured afterlife would be "quite enjoyable", and he claimed no fear of death.

7. Subject 8 said he used to worry about his illness all the time, but "that can drive you crazy". He figured "the less I had to think about my problems and my disease the better off I'd be." He had worried most about taking the mental stmin of the illness, but as the tests began to show consistant improvement and he suceeded in a summer job, he felt he had made it, and directed his attention to making the most from his experience. He recalled when he was really slck telling himself things like "When the going gets tough, the tough get going", and other cliches to keep himself going.

8. His life he rated as "overall a very good life--excellent, aside from this experience I went through last year". But now he saw himself as out of the woods and foresaw marriage and a career for himself in the future.

9. Subject 8 said that his goals had not changed, but that he appreciated things more, like school: "When other students think it is boring, it still beats the heck out of what I was doing before." And when tempted to use the excuse of being sick to get out of a test, he would tell himself, "If you do that, you really 
haven't learned much from this experience." Also, his initial crisis period had put his daily problems in a new prespective: "For the first time in my life I had a clear cut problem, a clear goal, and with a focus on one thing other problems fade, and so I had a clear conscience and a clear mind. As I made advances I took the old problems back, but I keep them in context, and try not to let them get blow up out of perspective again... But I still fall back Into bad habits--It's a constant effort to keep improving. If I don't appreciate nice days, my family, my friends, then it was just a waste to go through this."

POI data. Subject $8^{\circ} \mathrm{s}$ Ti:Tc ratio was high in the selfactualizing range as was his $0: I$ ratio. His highest subscales were in Capacity for Intimate Contact, Self-Regard, and Self-Actualizing Value; his lowest were in Synergy and Self-Acceptance. He had just two T1 answers; one was a Future item and one an Unconnected item, and both items he indicated he would have answered differently, 1.e. Tc, before.

Time attitudes data. Subject 8 gave just one Ti response, that being on an Unconnected item. He found every day to definitely be a fresh opportunity; he agreed that he could work hard and then relax and forget work, although he thought he had more trouble with that before his illness. He was neutral on being disturbed by nothing to show for a period of time, but he thought he would have strongly disagreed with that statement before. Subject 8 strongly denied feeling too worried about what might happen to be absorbed 
in the present, as he did with doing nothing because there was too much to do. He strongly disagreed that time was fleeting and that the pace of life was too fast, but found a minute to be definitely too small to be useful. Subject 8 took an unattached position on the Attachment items, disagreeing that he liked owning usless items (although he would have agreed with that before) and strongly disagreeing that saying goodbye was hard for him. He would have given one Past and one Future $\mathrm{T} 1$ response before, disagreeing with "Work, then forget" and agreeing with "Need deadline". He subscribed to neither Attachment 1tem, although before he would have agreed with "Like owning".

Subject 9 was a 21 year-old married, black protestant woman who had two ch1ldren, ages seven and three. She had dropped out of junior high to have children. She had worked at a Burger King for a while, but at her doctor's insistnce, she had not worked since her last relapse. She had chronic myelogenous leukemia, which according to her doctor, had been- diagnosed four years before, at which time she had been given chemotherapy and had gone into remission until a few months before the interview. Subject $9^{\circ}$ s understanding of her illness was that she had some blood disorder, "a touch of sickle-cell", since early childhood, and that she had only been told she had leukemia a month ago. At the time of the interview she was in the hospital because of a blood clot, but was to be released soon.

1. Subject 9 did not have much understanding of her illness 
or her prognosis; she hoped they would find a cure for her, or at least be able to keep her going as she was.

2. She was quite pleased with her present doctor (the same woman hematologist that Subject 1 had), and she felt that the doctor would take care of her.

3. She said she didn't tell people that she was sick because ever since she was a child she had been teased for being sick. Her frlends had all told her that no one would ever marry her, but she had kept her illness a secret from her husband until after the marriage which had been a year ago. Having children seemed to have had the biggest impact on her relationships with people. She said that when she had her first baby she first found out that she had friends.

4. She percetved herself as having always been $i 11$ and allenated from peers, but by having a baby she had found some friends, and she was proud of her family.

5. Her religious beliefs were Christian.

6. To her, death was "the body turning to ashes and the soul going to heaven". She expressed no fear of death.

7. In response to the question on worrying, she said that she didn't think about her illness much, that crying was no good, and taking an overdose was no good either, since she had two children. She seemed to focus a good deal of her concern on her children, worrying that they, too, might get the illness.

8. Perceiving herself as having always been ill, she had 
trouble relating to the question cf changes in her life and attitudes since the leukemia.

POI data. Subject $9^{\prime}$ s Ti:TC ratio was in the non-selfactualizing range, as was her 0:I ratio. Of her subscale scores, Synergy was her highest, with Nature of Man, Constructive and Self-Acceptance also high; Feeling-Reactivity was her lowest, with Acceptance of Aggression and Capacity for Intimate Contact also 1ow. Of her nine $\mathrm{Ti}$ answers, four were Future items, two were Past Items, and two Unconnected. No before scoring was made.

Time attitudes data was not obtained from this subject. While she agreed to fill out the scale, none of the three copies given to her were recovered.

Patterns Across Subjects

Can people, then, make use of a glimpse of their death to Improve their living? From the reports of these nine people one might give a tenative "yes". At the height of the crisis of being diagnosed with a life-threatening illness or undergoing surgery or other trauma, some people experience a sudden clarifying of priorities, of just what is and what isn't important. Additionally, some people seem able to use their illness as a motivator to keep their priorities straight and to order their lives to fit them. However, there were no unanimous responses from these subjects on anything. There was no typical subject, no typical POI profile or pattern of responses to the time attitudes items. Subjects came from varying backgrounds, had varying experiences, and adapted in 
varying ways. Still, there were patterns, where a few of the subjects agreed on major items, and the following section will deal with these patterns.

The question that got the most agreement among subjects was the one on life satisfaction. Subjects 3 and 4 both clearly stated that their lives had always gotten better, and that they expected that trend to continue. Subject 2 said her life had always been good but had been enriched since her diagnosis with cancer, and she expected the richness to continue. Subject 8 sald his life was excellent except for the year he was so sick, and that he had big plans for the future. Subject 6 said her past was good but she had felt Inferior; her present was good but she wanted more; and for the future, she expected the best. These five subjects could be called optimistic. They contrast most sharply with Subject 5 who sald her past was hard, her present was hard, and she expected her future to be the same. Subjects 1 and 7 remembered happier pasts, but Subject 1 was now just trying to ride out the discomforts of old age, and Subject. 7 sald he was trying to establish a better balance of enjoying himself as well as working, a balance he had lost when he started college. Subject 9 had found her past hard, although it had gotten better when she had a baby, but still her life was not easy. It was not clear what she foresaw in her future.

Optimism among these nine people seemed more a function of personality than of situation. Subject 4 was not in an objectively 
hopeful situation, but he had picked out one aspect of his life that had improved, his marrying, and he chose to focus on that. Subjects 2 and 3 , while realistically in better situations than Subject 4, still focused on areas where they could still make progress, as in writing, and for Subject 2, on relationships and travel. Subject 2 clearly stated that setting goals and keeping her attention on them were important to her. For Subjects 6 and 8, both young and considering themselves recovered, there was a different tone. Subject 8 was strongly optimistic but felt compelled to be productive now and to make good use of his experience for improving himself. Subject 6 qualified her statements of life satisfaction, and she, too, was trying to be a better person now. A possible distinction between Subjects 2 and 3 and Subjects 6 and 8 was that Subjects 2 and 3 seemed more focused on the activities they were engaged in and enjoyed, even though goal oriented, while Subjects 6 and 8 seemed more focused on the achieving of the goals, rather than on the activities themselves.

Pessimism, too, was not due soley to circumstances. Subject 1, while not brooding over the major threats she faced of sickness and Incapacitation, still focused on the little threats, like the bed that would not fold up. Subject 5 was also facing a realistic threat, and she had been sensitized to the potential trauma by having experienced it twice before. But still it was her style to focus on it so much, to worry "to the point of obsession". Subject 7 appeared, at least on the surface, to be in similar shape as 
Subject 6--both were successful transplant patients, but subject 7 , a year and a half after the transplant, maintained his vigilance, protecting the kidney and watching for signs of rejection, while Subject 6 , less than a year after her transplant, had noted that people seldom had rejection crises after the first year and had decided she would keep hers "forever". Subject 9 seemed to alternately focus on how unhelpful people were and how alone she was and then on her children, who were the positive aspect of her life. How people worried was related to their optimism. Optimistic subjects tended to deny worrying, to worry for someone else, or to be able to turn off their worrying with some success. Subject 3 denied worrying about his illness, saying there was no point in it. Subject 4 worried more about his wife's health and future security. Subject 2 worried about her jaw but kept busy. Subject 8 decided that the less he thought about his problems the better off he would be, and he gave himself pep talks when necessary. Subject 6 said she didn't let herself get down or worry on "borrowed time". On the other hand, Subject 5 said she worried a lot about having another attack. Subject 1 worried about "crazy little things". Subject 7 worried about his kidney rejecting, and said he had experienced a lot of "diffuse anger" (See Appendix B). Interestingly, Subject 7 was also the only subject to admit to being afraid of death. Subject 9 appeared to worry about herself but also about her children, taking them for checkups and promising that if they got what she had, she would talk to them so that they 
wouldn't have to cry alone as she had.

Changes in values and attitudes seemed related to age as well as experience with 11lness. Younger subjects were more apt to have conversion-like experiences. This was most apparent in the two subfects who considered themselves recovered, both of whom had had a crisis point. Subject 8 who had experienced sudden paralysis, then surgery, radiation and chemotherapy had found himself, in the midst of crisis, with a "clear consclence and a clear mind" because "with a focus on one thing [surviving and getting well] other problems fade", and he had tried to maintain that clarity of perspective since then. That period had also made him more appreciative of normal, everyday activity, and he had tried to maintain that attitude as well, saying, "if I don't appreciate nice days, my family, my friends, then it was just a waste to go through this." Subject 6, whose first three weeks in the hospital had been full of pain and anxiety because the new kidney would not start working, prayed that she would be nicer to people if she survived, and she had worked to keep that promise since. Subject 7 also went through a crisis period getting his transplant, and came out of the hospital feeling more apprectative of sun and fresh air, and also feeling more tolerant of people. He was working to keep those changes. Subject 4 was somewhat older, and in a sense he had never come out of the crisis period into a period of remission, and he did not report this sort of experience. Subject 3 did have a crisis period and then a period of better health, but he denied any major changes 
In attitudes, saying the crisis of being in the war when he was young was the crisis that had helped form his attitudes and values. Subject 2 had minimized the life-threat of her early surgery experiences and only gradually, she said, come to realize she had cancer. She reported no crisis period that led to sudden changes in perspective, but she talked of a clear change of priorities beginning with her first surgery when her doctor told her to "do the things you want to do", and she had been actively ordering her life since then. Subject 1 denied any impact at all on her attitudes from her diagnosis with leukemia. The death of her husband and then her sister, along with her growing old and weaker had influenced her much more, she said. Subject 9, the youngest of the subjects, considered herself to have been sick since early childhood, and it was unclear how long she had known she had leukemia. In general she said the 11lness had not changed her attitudes or experiencing, and so she was not included in some parts of this discussion.

Subjects' self-perceptions were related to their optimism. Most subjects perceived themselves as having become stronger or having realized their strengths through the experiences they had with their illnesses. Of the optimistic subjects, Subjects $2,4,6$ and 8 clearly stated that they saw themselves as stronger, more courageous, able to withstand pain more or direct their lives more independently than before. Subject 3 saw himself as having become more effective, although he attributed this partly to just growing 
older. Subject 4 also attributed part of his increased independence on growing up. Of the pessimistic subjects, Subject 1 saw herself as having become "mean" with old age, although this apparently related to greater self-acceptance and less conformity. Subject 5 saw herself as weaker in that she didn't expect as much of herself anymore. Subject 7 , besides being more tolerant of other people did not note much change in self-image.

There were no general conclusions drawn from the POI profiles. The primary usefulness of this instrument for this study was as a second picture of each subject as an individual. The profiles were congruent for the most part with interview data. Generally more optimistic subjects described themselves as more self-actualizing; generally subjects who noted change on the POI saw it as change towards self-actualizing. Subject 5, whose profile was fairly low, indicated the greatest change scores, and all were in a positive direction. This might serve to point up the fact that comparisons across subjects may be misleading. if interpreted only in light of experiences with illnesses, since subjects were starting from very different places. There were two subjects who noted change away from self-actualizing, although each noted just three items changes. These were Subjects 3 and 8 , and for both, it might be interpreted as stronger self disipline and a greater concern for being productive.

Because of the suggestion in the literature that experiencing of time might change, as well as subjects' comments on their 
awareness of their use of time, the Tc scale of the POI was looked at further, in terms of the Fast, Future, and Unconnected items. In addition, the time attitudes scale was given and Past, Future, and Unconnected items looked at. There did seem to be some consistency within subjects on these two measures, validating the time attitudes items that were chosen for those catagories. There was also consistency between subjects' self-reports in the interviews and their responses on the scales. Subject 8 , who said he didn't think much about problems gave the fewest $\mathrm{Ti}$ answers, giving no Past responses, just one Future response and one Unconnected response. Both of these $\mathrm{T} 1$ answers he thought he would have answered differently, 1.e., Tc before, which goes with his greater concern now for being responsible. He responded similarly on the time attitudes scale, giving no Ti answers for Past or Future items, and just one on Unconnected items. Subject 2, who admitted worrying and having some regrets had six $\mathrm{TI}$ answers on the POI, three Past, two Future, and two Unconnected. On time attitudes Items she had one Past, one Future and one Unconnected Ti answers. She also noted on the POI that she would have given four more TI answers before, two Future and two Unconnected, and on the time attitudes scale she would have given one more Future T1 answer. This fits with her statement that she was now more focused on doing things in the present than before, when she had looked more to the future. Subject 3 gave just five Ti answers on the POI, one Past and three Future; he gave no Ti answers on the time attitudes 
scale. This fits with his doing things that he enjoyed and was good at rather than worrying about future events he could not control. Subject 4 who also minimized his worrying about himself and who said he did not think too far in the future anymore, gave five POI TI answers also, two Past and three Future. Of the optimistic subjects only Subject 6 gave a large number of Ti answers; she gave two Past and four Future Ti answers, eight in all on the POI, and she gave four $\mathrm{T} i$ answers on the time attitudes scale, one Past, one Future and two Unconnected. One aspect of her "time incompetence" was probably her tendency to focus on a future, better time, as when she might marry. It should also be noted, however, that the three subjects with the highest POI Ti scores, Subjets 1,6 and 9 were the three subjects who had not gone to college, and POI scores tend to show more self-actualizing tendency with more education. Subject 5, who tended to focus on her worries, gave just two $\mathrm{T} i$ answers on the POI, one Past and one Future; she Indicatad tha she would have given nine more $T I$ answers on the time attitudes scale, giving one Past, two Future, and three Unconnected Ti answers, and indicating she would have given one more Future Ti answer before. A possible explanation for her low POI T1 score might be her claim of resignation to life as it was. Relevant to this is the fact that she gave no Attachment answers now, although she indicated she would have given one before. The Unconnected items on the time attitudes scale seemed to vary more directly with anxiety level among subjects than did the POI items. Subject 5 was 
also quite familiar with the POI, but her overall profile did not indicate she was giving herself inflated scores. Subject 7 was likewise reasonably low on POI Ti answers, giving five total, one Past, one Future and one Unconnected, and indicating he would have given one more Future $T i$ answer before. His time attitudes scale was somewhat higher in Ti answers, there being one Past, two Future and one Unconnected $\mathrm{Ti}$ answers with four neutrals and the indication that he would have given one more Future $\mathrm{T} i$ response before. One might reflect that his vigilance was still a present-focused activity, and he too had at least the intellectual level attitude that he should "watch the river flow" more, and enjoy himself in the present. Subject 1 gave $\mathrm{Ti}$ answers in a pattern similar to Subject 2 giving six POI Ti answers, two Past, and two Future, and Indicating she would have given two more Future and two Unconnected Ti answers before. On the time attitudes scale she gave one Past, one Future, and two Unconnected Ti answers. Subject 1, however, gave no Attachment answers, while Subject 2 put both Attachment Items in the strongly agree category. Subject 2 was still very much attached to people and things, whlle Subject 1 had disengaged to a large extent. Subject 9 on the POI gave $10 \mathrm{Ti}$ answers, two Past, four Future, and two Unconnected. The interviewer had occasion to talk to Subject 9 several times after the initial Interview, and each time she seemed depressed except for one, and that was when she had just found out that she was pregnant again. It seemed that having future events to look forward to were 
important for this subject's happiness, that her present was not comfortable for her. Subject $9^{\circ}$ 's lack of education may also be reflected in this score.

Overall conclusions from the $T i$ scales are speculative since there were not enough useful items on the time attitudes scale, nor were there enough subjects to determine significance of scores. However, the data is suggestive of hypothese that might be studied further. The majority of change scores consisted of dropping Future $T i$ answers, reporting less focus on concerns for the Future. Subject 7 might have predicted this when he commented that healthy people tend to think of the future as an infinite expanse of time, but that dialysis patients, like old people, related only to the short term future. Just having one's future cut off does not necessarily lead to time competence, however, since one could find that with no future to relate to, one's present activities were meaningless, which might leave one open to depression. An interesting contrast in this respect is between Subjects 1 and 2: Subject 2 believed in an afterlife and was oriented towards leading as rich a life here as possible partly because that would set her up better in her next one. Her focus, while more on present activity than before, still had direction given it by both short term goals, such as completing books and long term goals of evolution. Subject 1 , on the other hand, had no belief in an afterlife and seemed to be just living out her time in this one. Generally more optimistic and better defended subjects made use of 
religlous orfentations to give meaning to their lives. Subjects 4 and 8 seemed most defended and both were staunch Catholics. Subject 3 who was also well defended did believe in God, although his more important beliefs seemed to be in himself. Subject 6 , while belleving in relncarnation, did not seem to have a religious faith that was an organizing principle in her life. However, of the subjects who were more pessimistic, three denfed believing in God or an afterlife. The fourth, Subject 9, professed a traditional Christian faith.

The area of subject's defenses is an interesting one, since from the literature one could formulate contradictory hypotheses on whether denial disrupts successful adjustment or can be a part of successful adjustment. Judgements on the use of defenses by these subjects are tentative, since subjects were for the most part seen on only one occassion, in one situation, and no direct assessment was made in this area. There was no present outright denial of 11lness or of the threat to life among these subjects, but there was ample use of positive thinking, and focusing on strengths and assets, and most of it seemed adaptive. Subject 3, with the lowest apparent anxiety, seemed quite focused on his strengths, as well as keeping busy and goal orlented. His two lowest POI scales, Capacity for Intimate Contact and Feeling Reactvity, suggest he may have been less sensitive to himself and other people because of this, but his overall level of adaptation seemed quite high. Subject 8 also seemed well defended and in an adaptive way, shut- 
ting off excessive worrying and maintaining faith in himself and God over a long period of physical and mental strain. He also reported that when the paralysis struck him, he had not been too frightened because he had just been checked out at the Mayo Clinic, and so he figured there couldn't be anything too important wrong. It was only later that he fully recognized the danger he had been In. Subject 2 reported, similarly, not really accepting the awareness that she had cancer for years after her first surgery. Yet in both cases, this sort of denial reduced anxiety and did not Interfere with their seeking medical attention or other support. Subject 2, in fact, went ahead ordering her life as if it might end, in spite of her surface denial that she thought she might die. Subject 4 who was clearly the most limited by his illness, managed to maintain a fairly optimistic outlook in the face of daily frustration by focusing on his wife and his business and minimizing his present distress in a manner which may have included some elements of denial ("I am in as good of shape now as I was six years ago." "My life is better now.") Subject 6, while using positive thinking about her kidney, still seemed prone to doubts about herself and her future.

Subjects using very little denial included Subjects 1,5 and 7 and all seemed prone to anxiety and perhaps depression. Subject 2's present style of adapting also seemed to include little denial, but she had developed an activity-and goal-oriented focus that was working well for her. Subject 9 was prone to anxiety and depres- 
sion, but it was difficult for the interviewer to understand just how she dealt with her feelings, except that on occassion she appeared to use real denial or otherwise distort reality. 
DISCUSSION

These, then were the findings of this study: That people can undergo attitudinal and behavioral changes, when faced with a life-threatening illness, that include a clarifying of priorities and a stronger focus on present activities as opposed to future achievements. The younger people in this study with more traumatic initial crises were more apt to have an experience of sudden clarifying of perspective on what was and wasn't important, and then to try and maintain that perspective; older people did not have such dramatic experiences but were more apt to report a gradual solidifying of priorities under the pressure of time. Style of adjustment was more clearly related to personality style than to any other factor, including severity of illness. People who had the outlook that some important aspect of their lives or themselves was continuing to improve and progress seemed to experience less anxiety; religious beliefs were a common component of this outlook. A focus on the progressing aspects of life and on keeping busy seemed to be a common and successful style of adapting. Limits of the Measures and Subject Sample

The POI gave an interesting second picture of these people, but was less useful because of the resistance evoked in subjects by many individual items. Two of the nine subjects refused to answer a significant number of items (14 and 16), and most of the subjects complained about some of the required choices between items where "neither", "both", or "sometimes" might have been the correct 
answer. The time attitudes scale evoked less opposition and few complaints, probably because of the greater flexibility of the rating scale; still two itéms were omitted by two subjects. There were 12: "I live in the past.", and 13: "I live for the future." These two items, even though directly relevant to the Past and Future categories were not included because of the omissions. A large number of the other items were difficult to sort into any type of category and so were not tabulated, even though many were interesting as individual items. Some of the items seemed to contain more than one theme which made them difficult to interpret. An example of this was item 1: "Time is fleeting and precious. There is so little of it." The basic theme seemed to be the speed at which time passed, but a second element is the value of time. This scale would be more useful if a rationale were developed to facilitate the interpretation of responses, and then items were reworked to fit into appropriate categories more precisely.

The use of the "Different Before" scoring gave interesting data on several subjects and supported the idea that people may deal differently with time after receiving the diagnosis of a 1ife-threatening illness. This strategy depended entirely on subjects' retrospective reports, however. The possibility of obtaining real "before" and "after" data seems remote for studies in this area, although reports from family or friends who knew the subject before and now might help corroborate such evidence. Subjects 5 and 7 were most verbal about the influence just 
maturing had on their attitudes, confronting the influence of becoming ill. On the back of the time attitudes scale Subject 5 wrote:

"I found that because I had been sick for 9 years, since I was 22, many of the statement changes were a result of maturing. However, those related to time seemed to have a good amount of disease-oriented feeling."

Subject 7 wrote on the back of his time attitudes scale:

"It occurred to me that 'before I was sick' was when I was 19 years old--a mere baby. Thus some of the changes that have occurred (or rather I think have occurred) are a result of seven years of living and not my illness and some are attributable to my illness ( $I$ think)."

Their comments suggest that another way of using the time attitudes items, as well as some POI items, would be to use them as interview questions and have subjects explain what the item meant to them as well as why they responded as they did. An interview structured to explore the issues of time competence and priorities in a more systematic and in-depth way might be the most fruitful direction to take in following up this study. Subjects should be selected to include both older and younger people, although elderly people might be considered a different experimental group if they are included, since they are responding to all of the issues of old age as well as illness. As much as possible, the subject sample should be representative of the real population of people with chronic life-threateniug illness. This subject sample had a bias towards the career of psychology, due to the sources most available to this interviewer. People not so psychologically-minded may not 
experience time or priorities in the same way. Another bias in the study, more difficuli to eliminate, was that all subjects were volunteers and were people perceived by friends or doctors as willing to partake in the study. While future studies may also be subject to this bias, the limits of conclusions drawn from such samples should be considered.

A group of healthy people, matched to the life-threatened subjects for age and perhaps other background variables, would provide a useful control group for sorting out the effects of maturation from the effects of becoming i11. In a study comparing healthy and sick people, however, one should not necessarily assume that original level of psychological adjustment was normally distributed across both groups. Hutschnecker (1974) found his case studies to suggest that it was when people were unhappy, or their "will to live" was weakened, that they were most apt to become seriously 111. Also, a factor to watch for in looking at attitude changes in healthy people, is that any experience of pain or loss could be an experience of one's mortality, and so such experiences should be Identified and explored with subjects when they exist. 
So it seems to be in the matter of gaining new perspectives on what is important that the advice one's death is most directly applicable. Lauren Trombey said it gets one "to do the things that he could well have done [all along] to change his life for the better." Maslow said it as "everything...gets piercingly important." Casteneda, through Don Juan said, "In a world where death is the hunter, there are no small or big decisions. There are only decisions that we make in the face of our inevitable death. ( $p$. 62)." 


\section{Keferences}

Abrans, R., \& Finesinge:, J. Guilt reactions in patients with cancer. Cancer, 1953, 6, 472-482.

Castaneda, C. Journey to Ixtlan. New York: Simon \& Schuster, 1972.

Chodoff, P., Freedman, S., \& Hamburg, D. Paper read at the 119th annual meeting of the American Psychiatric Assocation, St. Louis, May 6-10, 1963.

Davies, R., Quinlan, F., McKegney, F., \& Kimbal, C. Organic factors and psychological adjustment in advanced cancer patients. Psychosomatic Medicine, 1973, 35, 464-471.

Feife1, H. (Ed.). The meaning of death. New York: McGraw-Hil1, 1959.

Feifel, H., Freilich, J., \& Heimann, L. Death fear in dying heart and cancer patients. Journal of Psychosomatic Research, 1973, 17, 161-166.

Friedman, M. Death and the dialogue with the absurd. In E. Wyschogrod (Ed.), The phenomenon of death. New York: Harper \& Row, 1973.

Gendlin, E., \& Shlien, J. Immediacy in time attitudes before and after time-limited therapy. Journal of Clinical Psychology, $1961,17,69-72$.

Glaser, B., \& Strauss, A. Awareness of dying. Chicago: Aldine, 1966.

Hutschnecker, A. Personality factors in dying patients. In $\mathrm{H}$. Feifel (Ed.), The meaning of death. New York: McGraw-Hill, 1959.

Hutschnecker, A. The will to 1ive. New York: Simon \& Schuster, 1974.

Janis, I. Psychological stress: psychoanalytic and behavioral studies of surgical patients. New York: John Wiley \& Sons, 1958.

Jants, I. Stress and frustration. New York: Harcourt, Brace \& Jovanovich, 1971.

Krant, M. Dying and dignicy: The meaning and control of a personal death. Springfield, I11: Charles C. Thomas, 1974 . 
Kubler-koss, $\mathrm{E}$. 으 deach and dying. New York: Macmilian, 1969.

Kublex-Ross, E. On death and dyıng. In E. Wyschogrod (Ed,), The phenomenon of death. New York: Harper \& Row, 1973.

LeShan, L., \& LeShan, E. Psychotherapy and the patient with a limited life span. In $E_{\text {. Wyschogrod ( }} \mathrm{Ed}_{\bullet}$ ), The phenomenon of death. New York: Harper \& Row, 1973.

Miller, J. Study of death draws interest of psychologists. APA Monitor, February 1975, pp. 1;5.

Nagy, M. The child's view of death. In H. Feifel (Ed•), The meaning 오 death. New York: McGraw-Hill, 1959.

Needleman, J. The moment of grief. In E. Wyschogrod (Ed.), The phenomenon of death. New York: Harper \& Row, 1973.

Nighswonger, C. Ministry to the dying as a learning encounter. Journal of Pastoral Care, 1972, 26, 86-92.

Sheehy, D. Rules for dying; a study of alienation and patientspouse role expectations during terminal illness. Dissertation Abstracts International, 1973,33 (7-A), 3777.

Shneidman, E. Deaths of man. New York: Quadrangle/New York Times Book Co., 1973.

Shneidman, E. Orientation towards death. In R. White (Ed.), The study of lives, New York: Atherton Press, 1966.

Shostrom, E. Personal orientation inventory manual. Educational and Industrial Testing Service, San Diego, 1966.

Sleeper, R. The resurrection of the body. In E. Wyschogrod (Ed,), The phenomenon of death, New York: Harper \& Row, 1973.

Tillich, P. The eternal now. In H. Feifel (Ed•), The meaning of death, New York: McGraw-Hil1, 1959.

Trombey, L A psychiatrist's response to a life-threatening illness. Life-Threatening Behavior, 1972, 2, 26-34.

Vernon, D., Foley, I., Sipowicz, R., \& Schulman, J. The psychological response of children to hospitalization and iliness. Springfield, I11.: Charles C. Thomas, 1965.

Wanl, c. The fear of death. In H. Feifel (Ed.), The meaning of death, New York: McGraw-Hill, 1959. 
APPENDIX $\underline{\text { A }}$ 
Appendix A

Interview Format

I. Introduction to subject

A. What the study is about: How people's lives are changed by chronic, life-threatening illness.

B. Why I am doing it: Reason for personal interest, and academic nature of study.

C. Confidentiality.

II. Identifying information

A. Name, age, marital status, religious and cultural background.

B. Family composition, living situation, education, occupation.

C. Telephone \# and address.

III. Disease Information

A. What is your illness? How sick are you? How do you feel pyhsically? , Physical limitations?

B. When find out? How told? What do you know about your disease? What is your medical prognosis? What do you expect? What do you worry about most? How much do you worry?

c. How have you felt through the stages of your illness, physically, emotionally?

D. How helpful have people been? Your doctors?

IV. Subjective Information

A. Your inage of the disease in fantasy, if you were to draw 
1t? Image of body? Foreigness of disease, body? Image of death, Thoughts about it? Image of life? What is happiness for you?

B. Why did it happen to you? Does it have meaning, created by you or intrinsic? Do you feel cheated? Do you experience things differently than most people?

v. Information on Change

A. Change in plans, goals, values? Procrastination? Philosophy of life--what makes it worthwhile, satisfying, purpose of life? Religion? Stages of change?

B. Change in daily experience? Interpersonal experience, dependency, separatness? Sensory experience?

C. Life satisfaction, past, present, future?

D. Change as a person? Self-concept? Independencedependence, strong-weak? Expectations of self? 
APPENDIX $\underline{B}$ 
Subject i

\author{
"I don't think about it much.... I worry about crazy, \\ little things."
}

Subject 1 was a nervous, thin, 78-year-old Jewish woman, appearing somewhat younger than her age. She lived by herself in a small apartment on the Near North Side. She had grown up in Chicago with her father, who was a tailor, her mother, and her sister who was two years older. She had gone through two years of high school, and had some music training, so she had taught piano during the depression to get a little money. She had hated it, but was glad to be able to help out with the family finances, since her husband didn't make much money. Her husband had been in scrap iron, but he had not done very well, she said. Now she had just enough money to afford a small apartment and not be stingy in tipping the doorman. Her husband had died 14 years ago, and her sister two years ago, and so she was frequently lonely. She had one son in California who had four daughters, and one daughter in the suburbs who had two daughters. She visited her son in California one month each year, and she said they wanted her to move out there, but she had friends as well as her daughter here, and so she stayed in Chicago.

Subject 1 had chronic myelogenous leukemia, but her real physical problems, she thought were just due to her age. "I'm old," she said, "I have a chronic bladder infection. I'm tired and don't sleep well. I can't entertain anymore because it is too tasking, too draining." About the leukemia she said, "I don't ask much and they don't tell me much. But I know it is chronic, and so I suspect it will outlive me--I'm 73." Subject 1 said that she first found out for sure that she had leukemia about two years ago, when her old doctor died. She had suspected it for a while before that, and so she asked her new doctor, who said, "Of course, didn't he tell you?" Subject 1 thought he hadn't the heart to tell her. She said her old doctor had been wonderful. Her new internist was okay, but she liked hapr hematologist much more. She said she didn't tell people about her illness, but she thought they knew she had it.

Death, she said, was not frightening to her, but being sick and unable to take care of her self was. She didn't want to get like some of her friends had gotten, unable to remember things and unable to care for themselves. "I want to go quickly," she said. "I don't want to suffer, and I don't want to be a blubbering idiot." When asked about her trust in her body, she said she had to take a lot of pills each day, but they seemed to work. Also, she had had a masectomy when she was 47 , which had left her arm lame enough that she no longer played piano. In recent years she had lost so much weight that she wore padding on both sides, which gave her the appearance of a youthful figure. Her daughter had also had a masectomy, and her sister died of cancer, so she worried about her granddaughters. 
Learning that she had leukemia had not changed her life much, she said, but growing old and losing her husband and then her sister had. She used to be strong for the sake of others; she had taken care of her husband and children, and then her sister while she was ill. But now, she said, "I just try to be a good companion to friends and amuse myself a little." She enjoyed music and had a season ticket to the concerts at Orchestra Hall. She also watched TV programs she wouldn't have watched before--but now she just wanted to be amused. She said she used to not procrastinate, but now she had so much time on her hands, it didn't matter. Subject 1 said that she had become "just like other widows--They get mean. You have to take care of yourself." She didn't much bother with people that she didn't like anymore. She still tried to be independent, but she wasn't as strong as before, and so she had to depend on others more. She had just gotten a new fold-away bed, but she found she couldn't fold it up by herself, so she had had to call her son-in-law to fold it up, and he had called the company to come fix it. She said she didn't worry about being sick, but she worried a lot about crazy little things, like the couch. Subject 1 was not religious, al though she wished she were, and she had no concept of a god or an afterlife, and that had not changed with growing old. It was family and friends, she thought, that made life worthwhile. Subject 1 sald that she tried to take things as they came, and not make a fuss of anything.

Subject 2

"After the faw operation I realized that in those $81 / 2$ years I really had done a great many things I wouldn't have done if I hadn't had the breast operation, and that life really had been pretty full, and it wasn't all so bad to have had that operation."

Subject 2 was a 58-year-old white married woman with a doctorate in psychology. She had taught college for 20 years, published two books, and had raised three children. Her sons were 29 and 27; her daughter was 25 and had just moved out of the home. Subject 2 lived with her husband, 69, who was an actuarian. She no longer taught, but kept busy writing, doing handiwork, volunteering for the Cancer Society, and taking trips with her husband.

Ten years ago she had a masectomy. She said they never talked to her then of cancer, but only of "the lump". She knew it was malignant, because three doctors told her she had to have her ovaries removed as well, since it had spread half way to the lymph glands. But after she had recovered from the scond operation, which was much more difficult than the first, she thought that she was okay, since it hadn't spread to the lymph nodes. However, she said, "It was after the breast operation the doctor said very seriously, 'Do the things you want to do.' Although we followed his advise and have thanked him since then, I don't think we really did it because we thought life was going to be too short." Even eight years later when they removed part of her jaw after cancer had been found there, and they used the word, "cancer" with her, 
she still thought that after she recovered from the operation that it was over. "I guess you could call it denial," she said. "Now I'm pretty well resigned to the fact that I have cancer, though it's taker me a long time to get this far. It really came home when the bone scan last fall showed it all over." It was now in her spine and ribs, as well as in her skull and lungs. She and her husband were now planning to put all of their property under his name, which had originally been put in her name, since she was 11 years younger.

At the time of the interview, Subject 2 had been feeling relatively well for about three months, the length of time she had been on a new medicine that seemed to have arrested her symptoms. Before that she had had pain in her bones in places where the cancer was. She had a chronically swollen arm from the masectomy, but she went swimming every day to keep the swelling down. Her main complaint was the jaw. "I'm terribly conscious of my face and mouth. It hurts, yet I can't feel inside of my mouth--I don't eat candy or I get it stuck and can't find it." She also didn't eat candy because she couldn't taste sweetness anymore. That taste, as well as part of her salt taste and most of the tactile sensation in her mouth had been destroyed by the operation. About a third of her lower jaw had been removed, from the hinge down to the second molar on one side, and she had a prosthesis which allowed her to talk and chew. Chocolate, she said, was awful, just tasting bitter. But, she laughed, for the first time in her life she had no trouble keeping her weight down. Still, she was bothered by her trouble with talking and said, "I wonder, how do I put up with this? It's so uncomfortable and so unwieldy! I've decided $I^{\prime} m$ never going to get completely used to $1 t$, the whole misshapen mouth." When she got tired she clenched her teeth and talked through them. She had taken a class for a friend for five weeks but had found she hadn't the stamina to talk for the whole hour. She would end up giving cursory answers to questions and feeling quite bad about that. Her one worry, she said, was that the jaw would get so numb and out of control that she wouldn't be able to get her mouth open.

How helpful had people been to her? Subject 2 was in general quite happy with her doctors. "They treat me as someone special. The surgeon who did the breast operation greets me and says he's so glad to see me--He probably is; I should have been gone by now." He was also the doctor who had given her "permission" to be gocd to herself, to do the things she wanted to do. And the surgeon who had removed the part of her jaw, she thought, was quite clever. He had not only left her with some functioning in the jaw, but he had designed a "jowl" on that side which mostly hid the scar and which was almost a perfect match to the jowl that had since developed on the other side. Subject 2 said that she felt the right to not suffer, to not feel pain, and that she was confident that her doctors could help her with that. Subject 2 was not so pleased with the standard American 
medical procedures which had been used on her, however. When asked if she felt cheated, she denied feeling that way about getting cancer in the first place, but about her treatment she said, "What can you do about it? You can't go back and do it over. You can only make changes in what you're going to do in the future. But I wish the doctors had done something sooner about the jaw. I was aware something was very wrong for a year before they operated." Other regrets she had were that it was less than a year after her ovaries were removed that they quit doing that operation since it didn't seem really to help anyone. Also she noted that now in Europe they do the biopsies for breast cancer and the masectomies at two different times, such that the woman had time to prepare herself psychologically, and also so that all of the lab reports can come in before the breast is removed. Then if the lab says that the cancer has already spread, as it had in her case, then there is not so much point in removing the breast.

But also, she claimed, her life had been enriched because of the cancer. "After the jaw operation I realized that in those 8 $1 / 2$ years I really had done a great many ghings I wouldn't have done if I hadn't had the breast operation, and that life overall had been pretty full, and it wasn't all so bad to have had that operation. By that time we had the pattern of doing nice things and treating ourselves so well, we decided to do even more of what we wanted to do." Subject 2 wrote an article explaining the five ingredients she thought were essential for moving into a richer style of life after a cancer operation. These were: 1) Permission, the attitude that the time you have left isn't worthless. 2) Challenge, circumstances to encourage the use of talents. 3) Desire, or commitment, someone counting on you. 4) Keeping busy, and 5) Persistence toward the goal. "Actually arriving at one's goals becomes a way of life, and when time seems short there's a particular satisfaction in seeing one's accomplishments materia1ize." Subject 2 said she was much more aware of how long tasks were going to take now. She had just started translating another book, and a long one, but she would not have started it without the promise from a friend to finish if she couldn't. But both of Subject 2's books had been written and published since her first operation. It was right after the operation that she and her husband started taking the trips they had always planned to take after the children were grown--They went to Europe, to Africa, the Near East, and South America. But also, there were more subtle changes. "I never used to spend more than $\$ 30$ on groceries," she said. "Now I never look at, prices." Her goals had changed. She could no longer teach, and she and her husband no longer talked of joining the Peace Corps when they retired. Also, "because of the cancer I do things that I know are going to be satisfying in advance and I cut out some of the unnecessary trivia. Like housework--I sort out the things that are most important and let the others go."

What was death to Subject 2? Peaceful, she thought, and it 
didn't bother her that she wouldn't Iive to be 80 or 90 . She had heard a Unitarian minister describe death as a metamorphesis in the nature of the change from fetus to infant. "The fetus, if it could ask, could get no answer to 'why am I here', and 'where am I going'. But how richly it interacts with its environment determines in some part how rich is its life after birth. I feel comfortable that the death of this life leads to richer life yet." Her operating rule was that you adapt the best you can in this 1ife, and then you are in the best position to do well in the next. What made life worhwhile for her was in "interacting with people in a supportive way, in doing worthwhile things, and in giving back to the world that has helped to make you I think everyone owes something back."

Why had this happened to her? Subject 2 said that she had once asked her doctor that question, and he had responded that some bodies just wear out faster than others. She accepted that answer; she was just on the lower end of the natural distribution. As far as physical reasons went, Subject 2 figured she had an inherited tendency to cancer, since her mother also had had a masectomy. She related the story: "It wasn't until after Father.had died and Mother had come to spend the summer with us that I knew.... I was so angry.!" She had been told by her father only that her mother had had some lumps removed. "She had big bosoms. It must have been hard for her.... It was a blow to me when my mother died. We had lived far apart, and while the children were growing we hadn't visited much. When she died, I felt a loss--We never really got started on all the talks we should have had...." Two years later Subject 2 had her own breast removed.

Had her relationships with people changed? Subject 2 said that she was amused that "People pay more attention to me--They don "t know how long they "1l have this relationship." Although it had saddened her to have to stop teaching, she found she had more time for building relationships. "I get closer to people now. I realize how important relationships are." But with new people Subject 2 usually didn't tell them about .; illness. Some people handled the disclosure well, but some $\operatorname{didn}^{2}$, and it was hard to tell beforehand which way a person would react.

Changes in herself? Subject 2 found herself more dependent, particularly on her husband. But also, "I am a lot stronger than I thought of myself as being; I have more courage." And she had taken more active steps to improve her life since the cancer had come: "I dare to defy the kinds of patterns that have become customary and do things a little differently."

$$
\text { Subject } 3
$$

"I've learned efficiency--I've become much more effective in the things I do. Probably this comes from just getting older and more experienced, but also the urgency of time macie me better faster.... My response was to figure out cleverer ways to do things." 
Subject 3 was a 52-year-old white psychology professor at a major university. He also was a writer, having published a number of children's books and a textbook. An attractive, forceful person, he played with his pipe and poked run at himself and others throughout the interview.

Subject 3 had been diagnosed with chronic lymphocytic leukemia 11 years earlier, when he had suffered very bad headaches and trouble with his eyes. "The whites of my eyes were almost as red as Coca-Cola machines. They thought that I was drinking heavily and staying up all night. But I wasn't." They told him he had 5 to 20 years to live, more likely 5 . Subject 3 said that he thought he was going to die, and he went home and put all of his money in his wife's name. However, "My reaction was not one of horror, like if it had been a social disease.... It was one of those things, given my way of living, you simply accept and go on to 'what do I do now?" Subject 3 explained that in the war he had seen many people die or lose an arm or leg, and he had had to deal with those issues then. "It didn't seem to me that having leukemia and knowing I was going to die sometime in the future was different from a lot of other things I'd seen."

His wife, however, had a much more dramatic reaction. They had been married for 16 to 17 years and had two daughters. She had converted to Christian Scientist some time after their marriage, which Subject 3, a non-practicing Methodist, accepted as her own business,although the issue of having the children go to Christian Scientist Sunday School had been a bone of contention between them for some time. When Subject 3 went into the hospital for diagnostic work, she had refused to visit him, in accord with her faith, and when she heard the diagnosis, she went home and cleared out the bank accounts, took her suitcase and left with the children. Her view of the illness was that it was due to sin, and she would only resume the marriage if Subject 3 identified the sin, repented, and became a Christian Scientist. In telling this story, Subject 3 explained that he believed there was a god, that his experiences in the war had convinced him of that, and he believed that religious doctrine was an important part of every culture--He had studied religion as a social phenomenon for his doctoral dissertation, and he claimed that if all memory of religious doctrine was wiped out one day, the next day people would begin creating new religions. But, reedless to say, the marriage was not resumed. When Subject 3 left the hospital ten days later, his only possessions were his car, boat, clothes, books, and his chess set. However, Subject 3 described his university as paternalistic, and explained that his checks kept coming and colleagues took his classes for him until he was back on his feet. Later he was to remarry, his daughters returned to $\mathrm{him}$, and at the time of the interview, the youngest was still living with him. But for the first year and a half he had to sleep sitting up, and he was sleeping 12 to 14 hours a day. His body, he explained, was dumping white cells into the veins in his eyes, causing the pressure to build in then, and he found that if 
he laid down, the pain became unbearable. So he sat up instead. He said he at one point had to decide between putting up with the pain or becoming addicted to morphine, so he learned to live with the pain. For a period of about eight months, the pressure in his eyes was tipping his lenses such that he couldn't see well enough to drive, or worse, to read.

"That was distressing, for me," he said. He started 1istening to the radio more. Much of his difficulty at the beginning was caused by an infection which was treated and eventually cleared up, but even after that he continued to sleep 12 to 14 hours a day. "People simply adjusted to that. The university gave me afternoon classes; I arrived at school for the day around noon and left by five, but I put in more hours of actual work than most university professors, anyway," he said. His publishers learned to schedule no meetings for him early in the day, and even when he got back to sleeping 8 to 9 hours, they always allowed him time for a nap around 4 or 5. "But they were doing me no special favors. If they could have gotten someone better than me, they would have, and we both knew that. But the caliber and quantity of my work was such that they were willing to accept this."

Subject 3 explained that he had always been on an achievement slope, and that becoming $i l l$ had not changed his goals or values. But it did" put a limitation on time. "I feel less time to accomplish certain things, so in chosing among alternatives, I concentrate on those things of greatest profit. But I still get in time on the beach and sailing. I've learned efficiency--I've become much more effective in the things $I$ do. This probably comes from justgetting older and more experienced, but also the urgency of time makes me better faster." How did he choose what was of most profit? "You do those things that make you happy, and make others happier-There is little enough you can do for others..... 'd like to leave a good book or two that people would read and enjoy after I'm gone." He had written 18 children's books, and "kid's like "em," he said. He'd written college texts that won awards and provoked students to write him and thank him. Together his books had sold a quarter of a million copies. He also wrote for films, and had gotten an international award in that field.

Since his eyes had cleared up, Subject 3 had had no major physical crises, but over the years he had been gradually losing strength and endurance, such that over a period of a few years it was "distinctly noticeable." Subject 3 had been quite athletic. He had grown up in the north woods and had worked as a lumberjack in his youth. When he started college he had been an "athletic mercenary", although athletics had diminished in importance after he found that he could do quite well academically." "I used to be able to pick up a cement sack with my thumb and forefinger--That's 100 pounds--and throw it up on a loading dock," he boasted. "Now If I have to patch something with cement, I open the sack and take a scoop and put a little in a pail and carry it that way.... I have 
to use my head to figure out how to do those things I use to do, without getting into trouble. If I tried to pick up a cement sack now, I would probably strain something and it would take me four wecks to get over it." He still sailed, but now he sailed closer to the shore, and always wore his life preserver. "I had a heart attack once. It was from over exertion. I'd swum out 150 yards into the Carribean, and it blew the bottom out of my heart. But I also swam the 150 yards back in. Then I had to take care of my heart unt 11 it mended. So I learn from experience." Subject 3 explained that when he quit dumping white cells into his eyes, he had started dumping them in his chest cavity, and it had collapsed his right lung. "I just don't pump enough oxygen to run. If $I^{\prime} d$ have to run five steps to catch an ' $e I^{\prime}$, I'd let it go and wait 20 minutes for the next one." If he capsized his sailboat he'd sit on the bottom of it and suck his thumb until someone came rather than try to swim to shore. But Subject 3 emphasized that he did not feel diminished by his decreasing physical strength. "I've gotten better at all of the things that I do that don't call for physical strength," and for those, "My response was to figure out a cleverer way to do things." He denied feeling cheated, nor did he have any sense that there was reason or purpose in his illness. "That would presuppose some greater power specifically interested in me and manipulating me," he objected.

Subject 3 said he didn't worry about his health, but was more Inclined to be irritated by it. There was nothing he or the doctors could do about it, and thus no point in worrying. He was more than satisfied with his medical treatment. The hospital he'd been in was "marvelous". "Even the food was good." His trust in his doctor was complete. The doctor had refrained from putting Subject 3 on chemotherapy, against the advice from other doctors. His rational was that while chemotherapy might help him for a few years, it would also wear down his body such that he would probably die after the usual five years. He had judged by Subject 3's good consititution that he would do better than that on his own, so he had only treated him for infections. He had also avoided surgery, such as might have been done to clear his chest cavity. Now the medical consensus was that the doctor had been correct.

Subject 3 said he had never talked to people much about his illenss. "People don't know what to do, and they' re embarassed." But they had felt a lot of real concern for him during the initial period of his illness. But more interesting, he thought, was people's reactions when he didn't die at the scheduled time. People would give him funny looks, as if to say, "Here we've put all of this worry into you, and you "re still here!." And then the relationships reverted back to normal.

As for Iife satisfaction, Subject 3 said he was one of those lucky people for whom things always got better, and he was operating under the perhaps naive assumption that things would always continue getting better. His writing skills continued to improve, and he found writing highly satisfying. Retirement, for him, would mean 
more time to write. And death? "Probably one of these days I'11 catch a cold, and it will turn into pneumonia, and $I^{\prime} 11$ be gone in two days." Did he believe in any afterlife? Not really. Perhaps there was one, but he figured people weren't bright enough to be able to know that. And if there were one, he figured he would just adjust to that when the time came.

SUBJECT 4

"It's made me appreciate life more, appreciate those things I enjoyed but can't do now."

Subject 4 was a 36-year-old white Catholic man, married just seven months, unemployed, but with a college degree and several years of graduate school. He was uncertain what to call his illness: "They used to call it chronic renal failure, then terminal renal failure. Then they took out my kidneys, so I don't know what they call it." The interview took place in his small apartment with his wife present.

Subject 4 was a hemodialysis consumer of six years. He had survived two kidney transplants and rejects, and said he would not accept another transplant unless he could pick his own surgical team. An angry man, critical of the medical care he had received, Subject 4 commented that "people are essentially good, but they can't be trusted." (This remark was provoked by a POI item.) Subject 4 was quite limited in his activity, because of his low hematocrit, wich left him with little energy. He explained that he could walk about half a block before he would have to stop and rest. The day of the interview he had somewhat more energy than usual, because during his last dialysis some of his blood had been hemolyzed, and so they had had to give him a pint of blood, which had raised his hematocrit. So that day he had been very busy, taking care of business that he ordinarily lacked the energy to do. Subject 4 said that he was in as good shape now as he had been six years ago, and so the doctors didn't know how long he would live. He didn't expect to live as long as most people, however, and only planned for the near future. He said he did not worry about his health, but worried most about his wife and what might happen to her if he died. He worried a lot about money, and about his boat business, which he hoped to develop into a profit-making venture. In his interactions with his wife, he seemed to attend to her much as a nagging parent, and her health was more a topic of concern than was his. He said he was trying to teach her to not be so nervous and to take things easy. As an example, he was teaching her that if he didn't have the energy to take the pop bottles down one day, they could wait. Subject $4^{\prime}$ s slower movements, due to his low energy, added to his image as the steady, stable one of the pair.

Subject 4 had studied psychology, and he was convinced that his illness was purely physical. "After my first transplant I thought maybe I. was rejecting the kidney psychologically, but I watched it go for six months while the doctors did nothing--They said the drop in functioning of the kidney was not significant from 
week to week. But the trend was steadily down." Subject 4 was a staunch church attender and adhered closely to its doctrine. He understood the meaning of his illness in terus of his religion, and thought maybe it was a trial sent by the Devil. He said he did not feel cheated, because becoming ill had made his life better. "I've done important things, such as my work for the Kidney Foundation, and arranging the hemodialysis symposium." "It's made me appreciate life more, appreciate those things I enjoyed but can't do now." His ideas about death were basically Catholic, but had an additional dimension supplied by his own experience with being near death. Twice this had happened, that they thought he wouldn't make it, and both times, he said, it had been a very peaceful experience, and very comfortable. The last time had been when they had gotten air in his tubes while he was on the dialysis machine, and his heart had stopped. He remembered the board they had placed behind him while they pounded on his chest, trying to restart his heart, and he remembered thinking how comfortable it was, and that he would have to ask for it again. As he came to normal awareness, he realized it was actually very uncomfortable, and he asked to have it removed.

Subject 4 said that trees, people, and knowledge made life worthwhile. He thought it was great that man had finally gone to the moon. He was very interested in flying saucers. Subject 4 brightened up for the first time in the interview as he talked about flying saucers, and said that the trouble with scientists these days was that they had no imagination. He also stated that his wife would never understand this, but that he would even leave her to go on a space ship.

In response to the question on life satisfaction, he said that things always continued to get better. When he was first out of college he had an $\$ 18,000$ a year job and got to travel all over the United States. But life was better now, he said, because he had his wife. His change in self-concept was that he saw himself as stronger and more independent.

Subject 5

"I worry a lot--to the point of obsession.... I expect

the future to be no better than the present .... but there is some relief in that, in accepting that."

Subject 5 was a 30-year-old white female who had recently received her doctorate in clinical psychology. She lived in a small house in the suburbs with her husband, who was present through much of the interview. She had had lupus erythematosis-systemic for eight years, a disease of the auto-immune system, which in her case attacked her joints and blood. At the time of the interview she was in remission, and her only physical complaint was of some tiredness and some need to take good care of herself so as to not bring on another attack. She explained that she didn't know a lot about her illness; her doctor had encouraged her to not read up on it, and so she hadn't, and she didn't ask him a lot of questions. Her medical prognosis was uncertain. If the lupus did not attack 
her kidneys, she could theoretically survive any future attacks just as she had her first two. But her own expectations were that she would die of the lupus. She said that after she recovered from her first attack, she went into a period of denial, and that she convinced herself that it wouldn't happen again. But after her second attack the denial didn't work, and she was anxious all the time. She worried a lot about becoming sick again, to the point that it was an obsession for her, she thought. She tried to take good care of herself and not get too tired or worn down, in hopes of forestalling another attack. Death, she said, was not scary, but the body changes and the psychosis that the drugs had brought on in both attacks were. After both attacks she had spent several months hospitalized while gaining back normal psychological functioning, and she had spent a couple of years losing the weight she had gained and growing back the hair she had lost as a result of chemotherapy.

Subject 5 said she never talked much about her troubles of being sick to other people because she figured they couldn't really help, anyway. As far as her medical treatment went, she said she had enjoyed the regression allowed you in the hospital, but she had been mis-diagnosed and mis-treated enough times that she didn't really trust medical people.

Subject 5 said her image of her disease was as something foreign, almost like a deomon inside of her, and that her body, too, sometimes seemed alien to her. Her delusions while she was psychotic were of things growing out of her head and other bodily changes. She imagined death to be like going to sleep and experlencing nothing. She said she had feared death as a child, that her father had died when she was eight, but that she had worked out her death fears during her adolescence. She claimed no religious beliefs and no belief in an afterlife. She thought that most people lived much as she did, not experiencing supreme happiness, but just getting along. She said that happiness for her was an evening at home with her husband and with popcorn and a movie on TV. As to why had this disease happened to her, she figured it was a random event. It was not a punishment for her, nor was there any purpose for it. Each person, she thought, had obstacles in his 1ife. She used to feel cheated, especially when she found out that she couldn't become pregnant. She had spend four years working that out. Now she didn't feel as cheated.

Subject 5 said she didn't expect as much of herself as she used to before she was sick; she didn't push herself as hard. She felt more separated from people, but also she felt more selfreliant, except with those people she was very close to. She had become very dependent on her husband. Her husband felt that he had been made more independent by going through this experience with her. And while Subject 5 found little subjective improvement in hex life since her diagnosis, he felt that he had come to enjoy little things more, and to appreciate nature more. 
As for life-satisfaction, Subject 5 sald that her past had been hard; her present was hard, and she expected her future to be the same, but that she experienced relief in the acceptance of that.

Subject 6

"I expect the best; I'm going to keep it forever.... Why worry on borrowed time?"

Subject 6 was a 28-year-old white single woman, working as a secretary in a law firm, and living in a two bedroom apartment above her parents. She had been born in Hungary, and had moved to Chicago when she was 9. She was the oldest of three children, having a brother now 26 and a sister 19. She was raised Catholic, although she now considered herself agnostic. Her father was a cabinet maker and her mother worked in a factory. Subject 6 had finished high school and begun her first semester in junior college, but had quit to earn money to travel. She had gone to Europe in ' 69 for four months with her boyfriend. She also liked camping and wanted to go to Montana and to Canada. The only class Subject 6 had taken since then was an evening class in watercolor.

Subject 6 had a transplanted kidney. The story of her illness began in October of $' 73$ when her left eye had started giving her trouble. She went to the doctor and was diagnosed with high blood pressure and kidney damage. The doctor couldn't tell her what had caused the high blood pressure, although he said she might have had a kidney infection at some point, causing some damage, which would have caused her blood pressure to go up, causing more kidney damage. She was told that her kidneys would probably fail within a couple of years, and that she would then have to go on dialysis. They put her on a low protein diet and on medicine to lower her blood pressure, and they tested her kidney functioning regularly. The medicine, she said, had made her sluggish, slow witted, and "Impotent"--The doctors had denied that the medicine could reduce her sex desire, but from her experience, and from talking to others, she was sure that it had. She had just begun her job at the law firm, and she said that people there thought that was just the way she was, and when she was later able to reduce her medication, after the transplant, they thought that the transplant had caused a personality change in her, she was so energetic and witty. But that was getting ahead of her story. A year and a half after her diagnosis, in March of '75, Subject 6 first was put on dialysis. She said she could tell after the first treatment that it was worthwhile--she felt much better the next day. But still it wasn't easy. On really good days, she said, she just layed back for four hours, but she rarely had good days. However, the technicians there joked and were friendly, and "didn't let it get to you," she said, and so she actually looked foreward to going each time. She was on dialysis for. two months, and during that time she saw a man die on the machine. That was upsetting, she admitted, but she didn't think it was because he was on the machine that he died--she hoped. During those two months she decided to try a transplant, 
partly because she knew she couldn't go cariping as long as she was dependent on the machine to clean her blood three times a week. Both her mother and brother were good matches for her and were willing to donate a kidney; her sister was ruled out as too young, and her father as too old. Actually her brother was the closest match, she said, but her doctors decided on her mother, perceiving her as most eager to give her a kidney.

The transplanting was done in June of '75, and Subject 6 was in the hospital for four weeks. After the operation she ran a fever for three weeks such that they couldn't give her a full dose of immunosupressants, and the kidney would not start working. Subject 6 was miserable, depressed, and crying a lot, because she was afraid the transplant was a failure. She had to continue on dialysis, and she had one rejection crisis, which she felt coming on as severe, constant pain in the area of the kidney. But at the end of the third week her fever went down, her medication was increased, and suddenly the kidney started working. "I was up all night going to the john," she said. "It was wonderful!" In another week she went home, and at five weeks she was riding her bicycle. Her mother was a little longer recovering, she having the more difficult operation.

Now, she said, she felt fine. At first she had worried with every cramp she got that she was rejecting the kidney, but nothing ever happened. So she quit worrying. She ate what she pleased, she went camping, she moved quickly and didn't worry about running into something and bumping the kidney. The medicine she was on had caused her to grow extra facial hair, which she didn't like, and had made her cheeks look fatter, but otherwise she had no complaints. She expected the best. She had talked to other transplant patients at her checkups and said that no one seemed to get rejections after one or two years. The longest someone had kept a transplanted kidney so far was 19 years. She expected to keep hers forever.

People had been very helpful to her, she said. Her doctors and the dialysis technicians were good, and she got a lot of support from family and friends. "I have a big family," she said, "and it comes in handy." "When I was in the hospital, I got. so many flowers I could have opened my own florist shop..... And I got 12 nightgowns." She thought that since she had been sick, her mother had become more concerned about her, and made her the center of attention at home. She felt closer to her mother than before, and thought they had developed more of a friendship now, as we 11 as a mother-daughter relationship.

Subject 6 said she trusted her body to take care of her and her new kidney. She figured that her kidney failure was just one of those things that randomly happen to people. "Some things are random, like this, and some things you cause." Happiness she found in materlal things, she admitted apologetically, like camping and traveling. She said she had changed none of her goals, but that her values had changed some--She didn't scoff or belittle anyone 
for anything anymore. "In the hospital lots of people prayed for me, and so I prayed, too, and promised to be nicer to people, not so short, if I survived." Not that it was easier to be tolerant, but she tried harder. Death, she thought, led to reincarnation, and she wasn't afraid of it. She was afraid of pain, but she also thought that she could tolerate more pain than most people now. Her friend, she noted, was afraid of childbirth, a natural event, but she had been through a kidney transplant, a totally unnatural sort of pain. She said that she didn't feel cheated that this had happened to her. On the contrary, she felt that she had cheated her fate twice now. The first time had been in Europe when she had been in a car that was hit by a train going 40 to $60 \mathrm{MPH}$. She had gotten out with a broken arm. "I figured after that I could risk the danger and the pain of the transplant." And so she cheated her fate the second time when she received a third kidney. "Sometimes I get depressed, even if nothing is wrong--not that things are a11 that great. Anyway, I think then, who knows how long I'll have it, so why worry on borrowed time? I try to make the most of this borrowed time. I don't do much different, but my frame of mind is much better--I won't let myself get depressed."

Her past, she said, had been good, but she had been unsure of herself, and felt inferior. She felt more sure of herself now, but saw herself as dependent on friends and family, e.g. she would not want to leave Chicago because her family was here. She thought that maybe she painted to overcome her sense of inferiority. She sald her present life was good, but she always wanted more. For Instance, she wanted to marry, but she expected things to continue getting better in the future.

\section{Subject 7}

"I'11 never reach that stage [of acceptance of death]! I'11 go out kicking and spitting to the end!"

Subject 7 was a 26-year-old white graduate student in psychology who looked five to ten years older than his age--He explained that he had skin changes due to some of the medicine he was taking. A divorced man, he was then living alone. He had grown up the youngest of three children in an Irish-Catholic family in Boston, where his father was a laborer. Subject 7 had been the rebel of the family, growing his hair long, turning atheist, and getting a divorce, but he had been well tolerated by the family, since he was the baby of the family. His memories of childhood were happy; he had enjoyed grade school and high school, and he had been very close to his mother. When he went away to college, however, it was quite a blow to him to find himself suddenly away from home and family. He also was unsettled by finding college work harder than high school. In retrospect he saw himself as settling into academics and forgetting to take time to enjoy things. It was a year later that he went to the student health center because he wasn't fecling good, and he was diagnosed with chronic renal failure. At the time, he had little idea of just what that meant, and they gave him some medicine and he immediately felt better. However, 
the biopsy was a painful shock to him, and it was his first time in a hospital. Gradually he got more information about his illness as gradually he got worse; but he adjusted his activity as the illness progressed, and so he noticed iittle change in himself in the first few years. Three years later, however, in $' 72$, he was suddenly confronted with the whole picture, when he carried his medical records between doctors and read through them. A report by a renal specialist whe had seen him stated that he would be in a state of severe renal failure within two years. Subject 7 demanded an explanation of that from his new doctor, and got it. That same year his mother died of cancer, after having been sick for four years, and Subject 7 got his divorce the next month.

With the knowledge of the impending demise of his kidneys, Subject 7 felt the first pangs of the "Pango-Pango Conflict": This was the indecision of whether to stick to business as usual and continue working hard in school, working for future rewards, or to run off to Pango-Pango land and live it up while he could. That next summer, however, after moving to Chicago and beginning graduate school, he found himself totally exhausted after playing tennis, and he realized he had waited too long to go to Pango-Pango land-he was now too sick.

At his sister's wedding that summer he announced his need for a kidney donor. He predicted that his brother, who could never say no, would volunteer, as he did, and he was found to be an A-1 match. Meanwhile, Subject 7 managed to delay going to dialysis for six months by rigidly restricting his diet. He went on dialysis in January of ' 74 , and after the first two months of adjusting to the change in lifestyle, he felt much better and was playing tennis agaln. He continued to go to school on a lighter workload, realizing that to drop out of school would be to loose his social support system. Subject 7 figured he was 1uckier than most people on dialysis: He found the diet easier to follow since he was into no "food trips", and he was still producing some urine and so could have more fluid than many. In addition, he judged himself to be in better physical shape than most, and he continued to exercise to keep in shape. Subject $7^{\circ}$ s colleagues on the dialysis machines, however, were mostly poor black men with little education, since he had no health insurance and was being treated through the government program. He said many of them had gotten no medical treatment until their kidneys had suddenly given out completely, and so they were very sick when they started dialysis. Subject 7 found these people to be a philosophical group, however. Each man spent four to six hours on the machine three times a week, and so had plenty of time to think. "If you have the energy, enjoy yourself" was the philosophy of the dialysees. Subject 7 found himself avoiding parties, however, because the snack foods and alcohol were off his diet, and he didn't have the energy, and so he spent a lot of time alone.

The summer of '74, while Subject 7 and his brother, a school teacher, were both on vacation, the kidney was transplanted. 
Subject 7 said that the hospitalization and resultant loss of social roles, the pain and anxiety, and the drugs and the mania they caused, were an "outragious experience". He had three rejection crises and was in the hospital for four weeks, and because of the operation and the drugs he experienced major body changes:

Much of his hair fell out, muscles atrophied, and he found himself with a paunch in place of his formerly flat stomach. In addition, not long after his discharge he went roaring back to his doctors accusing the drugs of making him impotent. They apologized, saying that they had neglected to warn him of that since they had not expected him to worry about that for a while. But his medication was reduced his hair grew back, and his muscles and potency gradually returned. During this post-hospitalization time Subject 7 recalled he throughly enjoyed just being out in the fresh air and sunshine again. He also found himself more tolerant in relationships. These changes, he said, he was trying to maintain.

Subject 7 was continued on immuno-supressants as well as medicine to reduce his blood pressure. He understood that the longest anyone had kept a transplanted kidney was 15 years, and so he hoped for 10 to 15 years of reasonably good health, if he got in no accidents that might damage the kidney, which was less protected than his own kidneys since it had been placed in the front of the abdomen, and also he had to avoid getting any major infections that might necessitate going off the immuno-supressants. He figured after that he could always go back on dialysis, but he said it would be difficult to return to that lifestyle. He talked about not trusting his body as much as before, and he operated under the "airplane fantasy": When he was in a plane, he felt that if he could just stay awake during the whole flight and watch out the windows, then he would see any danger coming and could run up and warn the pilot, and so avoid a crash. He said that he had read up all about kidney failure and paid close attention to any signs that his kidney might be rejecting. This was partly for the good reason that he could then get immediate medical attention if he needed it, but it also served to build up his sense of control over his iliness.

Before getting his transplant, Subject 7 had explored the idea that there was a psychological aspect in his kidney failure, since the physical basis for the disease seemed to involve his immunological system attacking his kidneys. However, Subject 7 never was able to really relate to the idea that he was destroying himself. He also rejected the idea that God had sent the Tempter to him, or was puntshing him. And yet he experienced a lot of diffuse anger, wondering, "Why me?" Subject 7 said he ascribed no meaning or purpose to the illness, or for that matter, to life. But this issue was a conflict for him. He had called himself an atheist for some time, but now he found himself to be an agnostic. Death, he thought was a non-experience--like before birth. But still he was terrified of death, he didn't know why. Since childhood he had been facinated by the vampire myth, and with the idea of immor- 
tality, since becoming a vampire gave you eternal 1ife. He had explored the myth and said it occured in almost every culture in some form. Some people experienced the dialysis machine as a sort of vampire, he noted. Since his illness, he said, vampires had become an obsession. And Subject 7 objected to Kubler-Ross's five-stage model for reactions to dying. He resented the idea that people fell into neat stages like that, and also he couldn't imagine himself reaching the final stage, that of acceptance of death. "I'11 never reach that stage!" he said. "I'11 go out kicking and spitting to the end.!"

In response to the life satisfaction question, Subject 7 said that his childhood had been the best time, and had been very good. College, when he got caught up in academics and neglected to take time to enjoy things, was not so good. Then there was the period of being ill, and now he said, things were getting better, but still were not as good as before. As for the future, he couldn't be sure. "Relatively healthy people," he noted, "see the future as an infinite expanse of time. But statistically, $10 \%$ of dialysis patients die each year. You get so you only think of the short term future." He likened the changed time perspective to that of old people. "Even old people don't think of death; it's not an organizing principle." But the future they related to was shortened.

He thought he probably procrastinated more in work than he used to; he let being $i 11$ be his excuse, and people let him get away with it. But he was trying harder to resolve the Pango-Pango conflict; he was trying to get a balance between achieving and helping others, and enjoying himself, and "watching the river flow".

Subject 8

"I always figured the less I thought about my problems, and my disease, the better off $I^{\prime} d$ be.... When you' re really sick and reaching out for help and support, you tell yourself cliches, like, 'If you can't take it, get out." Or, "When the going gets tough, the tough get going.'....People would come up to me and ask, "How do you take it?' I'd just have to look at them and tell them, "Look, there's really not a whole lot of choice--you either do or you don " $t . "$

Subject 8 was a 23-year-old white Catholic college student from rural Indiana. The youngest of six children, two of his sisters were Catholic nuns, and one a school teacher. One brother was in real estate and the other was still a student. Subject 8 lived with his father, who was retired, and his mother, who had come with him to the hospital that day for his tests and was with him during the interview.

Subject 8 had fourth stage Hodgkin's Disease (i.e., the most advanced stage), now in partial remission. He had been diagnosed a little over a year before, at Christmas-time. The year before that he had been sick on and off with flu-like symptoms, and had been quite sick for two and a half months. His family doctor had been 
unable to diagnose him, as was the next doctor he was sent to. Finally at St. Elizabeth's Hospital they biopsled his lymph nodes and established that he had Hodgkin's. He got the word from his coctor, however, after his brother in real estate had read up on Hodgkin's and told him that was 1ikely what he had. He was then sent to the Mayo clinic for the "staging", which was done just before the first of the year. "I had one bad experience," Subject 8 related. It was on his way home from Mayo's. He suddenly found himself paralyzed from the rib cage down. "I wasn't too scared because I didn't know much about medicine, and I figured nothing much could be wrong since $I^{\prime} d$ just been $X$-rayed.... It was only later that I was scared." He was rushed back to Mayo where they discovered a tumor on his spine and operated. Then began a series of 20 cobalt treatments. "If $I^{\prime} d$ been as strong then as I am now," he said, "it would have been pretty easy. But I'd lost a lot of weight." And the treatments weren't easy. But, "it was only a problem for a couple of months," he explained about the whole incident. The only residual effect of the tumor was some nerve damage in his feet which hampered him in quick sports, such as tennis and basketbal1. Then Subject 8 began treatments on a once or twice-a-week basis to deal with the Hodgkin's. "Therapy was pretty rough. From 11 to 24 hours after the injection I'd feel pretty downright lousy, and in no condition to do anything." But people were helpful to Subject 8, especially his family. "At first it was awkward for them. But then they would see me or have verbal contact with me and realize that I wasn't loosing my mind or going to pieces." He credited his family with giving him support and encouragement throughout his illness, and giving him a kick when he needed it. "But to tell you the truth, I had to be my own main support. When things would really get rough, they'd look to me to see how I was taking things--If I had crumbled, it would only have been a matter of time before they did, too." And Subject 8 sought little support outside of his family; with some of his closest friends, he said, the subject never came up.

What did Subject 8 worry about most? "I used to worry about everything, but that can drive you crazy." In answer to another question, he said, "I never thought about trusting my body, but I worried about taking the mental strain. I often thought, "Thank God I can sort these things out that are happening to me." "A major concern of his was about having the stamina to do "something worthwhile". The first summer after his diagnosis he was feeling somewhat stronger, and his town gave him the job of organizing the Iittle league teams and their games. Subject 8 enjoyed it and did a good job of it. Also by that time some of his tests were showing proof that treatment was giving him progress against the disease, and he began to feel he was out of the woods.

What were his fantasies about the disease? "I never thought about it. To tell you the truth, I never did like psychology because-I always felt that if you thought too much about the workings of the mind, you might brood too much.... I just kind of 
also felt the less I had to think about my disease, and all my. problems, the better off I'd be."

Why did it happen to him? "We11, if you mean what caused it, I used to have the theory that I was pushing too hard my sophomore year. But looking back, that isn't likely. Every sophomore does the same. I just don't have the immunity other people have." Meaning? "I try not to dwell on it much," but, "if I don't learn something from this and make the most of it, then $I^{\prime}$ ve sure been through a lot for nothing."

Did he feel cheated? "The only times I've been a little upset about this whole process is when my activities are restricted, like when I miss school life, dating, and school games because of treatments. Then I do feel cheated. But probably I'd find something else to gripe about--the girl I'd like wouldn't go out with me; anything--if I didn't have this. Everyone can find a gripe; it's pretty easy."

Subject 8 said that having Hodgkin's had not changed any of his plans or goals. He still looked foreward to finishing school and getting married. But, "when I first found out, I lived from winter to spring and from spring to summer. I can remember thinking I shouldn't buy a suit because I might not wear it more than two or three times. I wasn't concerned about dying, but just about spending so much money and then not being able to wear 1t. I'd rather use the money for a trip." Having Hodgkin's had slowed up his education some, though. Subject 8 had had to put off taking al1 of his harder courses because he lost at least four days a month for tests. "I had two colds this winter, but they wanted to see me each time just in case, because the treatments lower blood counts. So I loose more time." Subject 8 understood that therapy was just killing off cancerous cells, so there was no reason they wouldn't grow back, "so until there is a new treatment, I'11 probably have to continue with this treatment, maybe not so frequently, for the next few years.".

Subject 8 said he got the most enjoyment out of filling commitments and doing things that helped other people, "like when you wake up in the morning feeling good about something you did the day before." Meaning in life came, he thought, from "doing the best you can in your vocation or area of interest." His, he thought, was organizational work. Religion was important in his life, as it was for his family, and he considered himself a strong Catholic. His mother commented that a doctor had told her that he'd never seen anyone with a stronger faith than her son. Subject 8 also believed in an after life, and figured it would be "quite enjoyable", but he thought that his beliefs had not been changed by his experience of his illness.

What had changed was his self concept. "You have to have a high opinion of yourself after something like that." "People would come up to me and ask, "How do you take it?' I'd just have to look at them and tell them 'Look, there's really not a whole lot of choice--you either do or you don't." "You find'yourself when 
you're sick and reaching out for help and support, you tell yourself cliches, like, "If you can't take it, get out." Or, "When the going gets tough, the tough get going." Even now, when it would be easier to use the excuse of being sick to get out of a test, I tell myself, 'I you do that, you really haven' $t$ learned much from this experience. This is nothing compared to having to sit in a hospital and go through those crazy tests and treatments." "Subject 8 wasn't sure his dally experience had really changed, but he did appreciate things more: "This whole process had brought a lot of things into focus, how important things are, like school. When most students think it is boring, it still beats the heck out of what I was doing before." Also, "For the first time in my life I had a clear cut problem, a clear goal, and with a focus on one thing other problems fade, and so I had a clear conscience and a clear mind. As I made advances I took the old problems back, but I keep them in context, and try not to let them get blown up out of perspective again." "But I still fall back into bad habits-It's a constant effort to keep improving. If I don't appreciate nice days, my family, my friends, then it was just a waste to go through this."

And how about life-satisfaction? "Overall I'd have to say I have a very good life--excellent, aside from this experience I went through last year. of course there are periods in everyone's life that are miserable."

\section{Subject 9}

"Everybody has something; some people just don't know about it yet."

"Subject 9 was a 21-year-old married, black protestant woman, who was in the hospital for a couple of days at the time of the interview. There was some language problem in the interview--she had trouble understanding the interviewer's white Nebraskan accent, and the interviewer had trouble with her black South Side accent, but this did not keep Subject 9 from talking at great length. Subject 9 was in the hospital for a blood clot, but her ongoing medical problem was that she had chronic myelogenous leukemia.

Subject 9 had grown up in a poor family, one of five children. Her sister was now 30, she had twin brothers 28, and a younger brother, 16. Her mother had died when Subject 9 was 6, and Subject 9 thought she had died of leukemia and high blood pressure, and that she had inherited the leukemia from her mother. Subject 9 also said that, as a child, she had to take medicine that made her dizzy and spacy. She said she had not been able to play as much as the other children, and that they, had teased her about being a drug addict. She had dropped out of school in junior high when she first got pregnant. She said she had first learned that she had friends when she had her first baby. She now has a 7 year-old daughter and a 3 year-old son, and she has livd on ADC since that time. According to Subject $9^{\prime}$ s doctor, she had been diagnosed with CML about 4 years ago, had been treated then, and had been in remission ever since. Subject 9 at one point, however, stated that 
she had only been diagnosed a month ago, and she told about going to different doctors, and they had all said the same thing, and she ran home crying. Her friends had told her she didn't have it or she would have been dead by now, and her family teased her about being sick, she said. But her family also visited her in the hospital, and her father and brother told her to do what the doctor told her. She thought her doctor was good, and that maybe she could cure her, or at least keep her going as she was. She said she didn't think about the leukemia much, that crying was no good, and that taking an overdose was no good either, since she had two children.

Subject 9 had marrled about a year before. Her friends all had told her that no one would ever marxy her, but she had kept her illness a secret from her husband until after the marriage. She said it was better not to tell people, because they teased you.

In thinking about why this had happened to her, she said that eveyone had their own disease, that everyone would die of something, just that many people didn't know about it yet. She thought disease might come as a punishment for laughing at someone else with an illness. To her, death was the body turning to ashes and the soul going to heaven. "When God takes, he takes," she said.

Subject 9 thought that having leukemia had not changed her plans or goals. Her experience was that she had been sick all of her life. She wanted to go back to school and finish high school. Once she had thought she would go to college, but now she thought she would go to a trade school. She wanted to be a nurse, and she wanted to talk to people with diseases and tell them that they would feel no different than they had before they were sick. If her children got it, she would talk to them about it, because no one had talked to her, and she had had to cry alone. 


\section{$\underline{\text { APPENDIX }} \underline{\mathrm{C}}$}


POI Standard Scores for Each Subject

$\begin{array}{llllllllllllll} & & \text { Tc } & \underline{\mathrm{SAV}} & \underline{\mathrm{Ex}} & \underline{\mathrm{Fr}} & \underline{\mathrm{S}} & \underline{\mathrm{Sr}} & \underline{\mathrm{Sa}} & \underline{\mathrm{Nc}} & \underline{\mathrm{Sy}} & \underline{\mathrm{A}} & \underline{\mathrm{C}} \\ & 1 & 48 & 36.5 & 46.5 & 41.5 & 48.5 & 34.5 & 58 & 40 & 43 & 39 & 37 & 34 \\ & 2 & 48 & 62 & 62.5 & 57 & 59.5 & 65 & 58 & 60 & 53 & 64 & 63.5 & 56.5 \\ (\mathrm{NA}=14) & \mathrm{a} & 41 & 50 & 62.5 & 50 & 42.5 & 51.5 & 58 & 57.5 & 47.5 & 55 & 48 & 41 \\ & 4 & 51 & 60 & 66 & 50 & 54 & 61.5 & 62 & 60 & 57.5 & 55 & 63.5 & 56 \\ (\mathrm{NA=3}) & 5 & 54 & 47.5 & 52.5 & 55 & 54 & 45 & 35 & 50 & 47.5 & 47.5 & 45.5 & 46 \\ & 6 & 41 & 51 & 59 & 53 & 51.5 & 51.5 & 50 & 50 & 57.5 & 39 & 48 & 48 \\ (\mathrm{NA}=16) & 7 & 41 & 51 & 59 & 53 & 51.5 & 51.5 & 54 & 34.5 & 37.5 & 37.5 & 36 & 56\end{array}$

SA average in all scales, 50-60

a $N A=n u m b e r$ not answered 
APPENDIX D 
Time Attitudes Items with Positive and Negative Ratings and Significance Levels of Items that Differentiated Between Successful and Unsuccessful Therapy Clients In Gendlin and Shlien Study (Gendlin \& Shline, 1961, Table 2, p.70) ${ }^{\text {a }}$.

? 1. Time is precious and fleeting. There is so little of it. (SL. 02)

- 2. The pace of life is too fast for me.

+3. I still have time to do the things I want to do.

? 4. I'm afraid I won't be able to live a full life. (SL.0005)

- 5. Enough time will solve any problem, I feel.

- 6. I dislike change.

+ 7. I have enough time--if I lack something it is energy, or ability, but not time.

+ 8. Nothing in life is absolutely final--endings also lead to beginnings. ( $\mathrm{SH} .02)$

+9. Every day is a fresh opportunity for me. (SH. 005)

? 10. My day is usually well organized.

+11 . I live in the present. (SH.0005)

- 12. I live in the past. (SL.04)

? 13. I live for the future. (SL.025)

- 14. I may pretend that there is time enough to finish something even if I see that there is not.

- 15. It is very hard for me to work on a task at all if I feel that there is not time to finish it.

- 16. I'm often too worried about what may happen to be really absorbed in what is happening right now. (SL.0005)

- 17. I often do nothing at all because there are so many different things I ought to do. (SL.005)

? 18. Time passes very slowly for me.

? 19. When I start something I finish it. (SH.025) 
+ 20. I'm usually prompt.

? 21. I'm a slow thinker.

- 22. A minute seems too small an amount of time to be of any use.

? 23. An hour or a day with nothing to show for it disturbs me.

- 24. I often do things when the doing is no satisfaction, just to be able to look back on them. (SL.02)

- 25. I'm the sort of person who often doesn't know the time of day or the date.

+ 26. I work hard for as long as a job takes, then relax and forget it.

- 27. Having to do something spoils that thing for me, even though I might have liked it otherwise.

? 28. I need a deadline to get started. (SL.007).

? 29. It's a relief to find that something is impossible, because that means I can drop it.

+ 30. A challenge is stimulating to me. ( $\mathrm{SH} .04)$

? 31. I always do my best to carry out my obligations.

- 32. I like to own things, even if I can't use them.

? 33. I need situations in which I know what can and what can't be done. (SL. 04)

- 34. I often don't ask for more of something because I hate to be refused.

- 35. I am often pushed into things I didn't want to do. (SL.04)

? 36. It is hard for me to say goodbye.

- 37. To be satisfied with a relationship, I have to feel that the other person is not withholding anything. (at pretherapy SH.005; at post therapy N.S.)

a Judges' ratings appear before each item. The parentheses after items indicates the level of significance at which post therapy sorting of the items differentiated successful from unsucessful clients. SH means the success group was significantly higher, SL that it was lower. 
APPENDIX E 
Time Attitudes Items Used in Results, Their Abhreviations, and Direction of Scoring

Past T1

9. Every day is a fresh opportunity for me. (Fresh opportunity) ("Agree" is in Tc direction)

23. An hour or a day with nothing to show for it disturbs me. (Nothing to show) ("Disagree" is in Tc Direction)

26. I work hard for as long as a job takes, then relax and forget it. (Work, then forget) ("Agree" is in Tc direction)

\section{Future Ti}

16. I'm of ten too worried about what may happen to be really absorbed in what is happening right now. (Too worried) ("Disagree" is in $\mathrm{Tc}$ direction)

17. I often do nothing at all because there are so many different things I ought to do. (Do nothing) ("Disagree" is in Tc direction)

24. I often do things when the doing is no satisfaction, just to be able to look back on them. (Do to look back) ("Disagree" is in Tc direction)

\section{Unconnected $\mathrm{Ti}$}

1. Time is precious and fleeting. There is so little of it. (Time fleeting) ("Disagree" is in Tc direction)

2. The pace of life is too fast for me. (Pace too fast) ("Disagree" is in Tc direction)

22. A minute seems too small an amount of time to be of any use. (Minute too small) ("Disagree" is in Tc Direction)

\section{Attachment}

32. I like to own things, even if I can't use them. (Like owning) ("Agree" is in attached direction)

36. It is hard for me to say goodbye. (Hard goodbyes) ("Agree" is in attached direction). 
APPROVAL SHEET

The thesis submitted by Teresa Foreman has been read and approved by the following Committee:

Dr. Patricia Berger, Chairperson

Professor, Psychology, Loyola

Dr. John Shack, Professor,

Psychology, Loyola

The final copies have been examined by the director of the thesis and the signature which appears below verifies the fact that any necessary changes have been incorporated and that the thesis is now given final approval by the Committee with reference to content and form.

The thesis is therefore accepted in partial fulfillment of the requirements for the degree of Master of Arts.

$\frac{4 \text { May } 77}{\text { Date }}$

Patricia MU Bayer

Director's Signature 